\title{
Silurian microplankton from the Cachipunco Formation (Santa Bárbara Range; Andina Central Basin), Jujuy, Argentina
}

\author{
María Fernanda de INUNCIAGA ${ }^{1}$ \& Pedro Raúl GUTIÉRREZ ${ }^{2}$ \\ 'Sección Paleopalinología, Museo Argentino de Ciencias Naturales "B. Rivadavia”, Av. Ángel Gallardo 470, \\ C1405DJR Buenos Aires, Argentina. fernandainunciaga@gmail.com ${ }^{2}$ Sección Paleopalinología, Museo \\ Argentino de Ciencias Naturales "B. Rivadavia”; CONICET. Av. Ángel Gallardo 470, C1405DJR Buenos Aires, \\ Argentina. pedroraulgutierrez@gmail.com.
}

\begin{abstract}
The palynological content of Cachipunco Formation is described in this contribution. This formation lies in the Santa Barbara Range, Jujuy Province, and outcrops at two localities: Angosto Los Pereyras and Cumbre los Pereyras. The more complete succession is the one from Angosto Los Pereyras, where the formation comprises $273 \mathrm{~m}$ of dark siltstones interstratified with thin sandstones and without visible base or top. The microfloristic associations are characterized by the presence of: Ammonidium ludloviense (Lister) Dorning, Barbestiastra barbata (Downie) Sarjeant \& Stancliffe, Domasia quadrispinosa Hill, Leiofusa exilata Dorning, L. parvitatis Loeblich, Multiplicisphaeridium arbusculum Dorning, M. eoplancktonicum (Eisenack) Lister, Neoveryhachium carminae Cramer, Proteolobus cylindricus Al-Ruwaili, Tylotopalla maraca Díez \& Cramer, T. robustispinosa (Downie) Eisenack et al., Veryhachium trisphaeridium Downie, and Ambitisporites avitus Hoffmeister. According to the stratigraphic distribution of the theses species, the age of the Cachipunco Formation can be constrained to a Wenlockian-Ludlovian range. A new species is proposed Multiplicisphaeridium baldisii sp. nov.
\end{abstract}

Key words: Acritarchs, biostratigraphy, Middle-Upper Silurian, Cachipunco Formation, Santa Barbara Range, Jujuy, Argentina.

Resumen. Microplancton Silúrico de la Formación Cachipunco (sierra de Santa Bárbara; Cuenca Andina Central), Jujuy, Argentina. En este trabajo se describe el contenido palinológico de la Formación Cachipunco, proveniente de dos localidades (Angosto Los Pereyras y Cumbre Los Pereyras) de la Sierra Santa Bárbara, Provincia de Jujuy. En Angosto los Pereyras, donde la Formación Cachipunco presenta la sección sedimentaria más desarrollada ( $273 \mathrm{~m}$ de potencia), incluye pelitas negras interestartificadas con arenisacs finas; sin base ni teschos visibles. Las asociaciones microflorísticas están caracterizadas por la presencia de: Ammonidium ludloviense (Lister) Dorning, Barbestiastra barbata (Downie) Sarjeant \& Stancliffe, Domasia quadrispinosa Hill, Leiofusa exilata Dorning, L. parvitatis Loeblich, Multiplicisphaeridium arbusculum Dorning, M. eoplancktonicum (Eisenack) Lister, Neoveryhachium carminae Cramer, Proteolobus cylindricus Al-Ruwaili, Tylotopalla maraca Díez \& Cramer, T. robustispinosa (Downie) Eisenack et al., Veryhachium trisphaeridium Downie y Ambitisporites avitus Hoffmeister. A partir del registro estratigráfico de estas especies la sección fosilífera de la Formación Cachipunco Formation puede ser referido al intervalo Wenlockiano-Ludloviano. Una nueva especie es propuesta: Multiplicisphaeridium baldisii sp. nov.

Palabras clave: Acritarcas, biostratigrafía, Silúrico Medio-Superior, Fomación Cachipunco, Sierra Santa Bárbara, Jujuy, Argentina.

\section{INTRODUCTION}

During the Silurian, in the Central Andean Basin (Fig. 1.1), that extends from Peru to North-western Argentina (Benedetto et al., 1992), a thick and fossiliferous, siliciclastic succession was deposited, which appears nowadays deformed and dismembered due to the Andean tectonics. In North-western Argentina, the most important outcrops of this succession are those from the Subandean Range, especially the ones from the Zapla and Santa Barbara ranges, in Jujuy and Salta provinces.

In the Zapla range (Fig. 1.2), the main litostratigraphic units are Zapla Formation (Schlagintweit, 1943) and Lipeón Formation (Turner, 1960) while at Santa Barbara range, the correlative litostratigraphic units are 


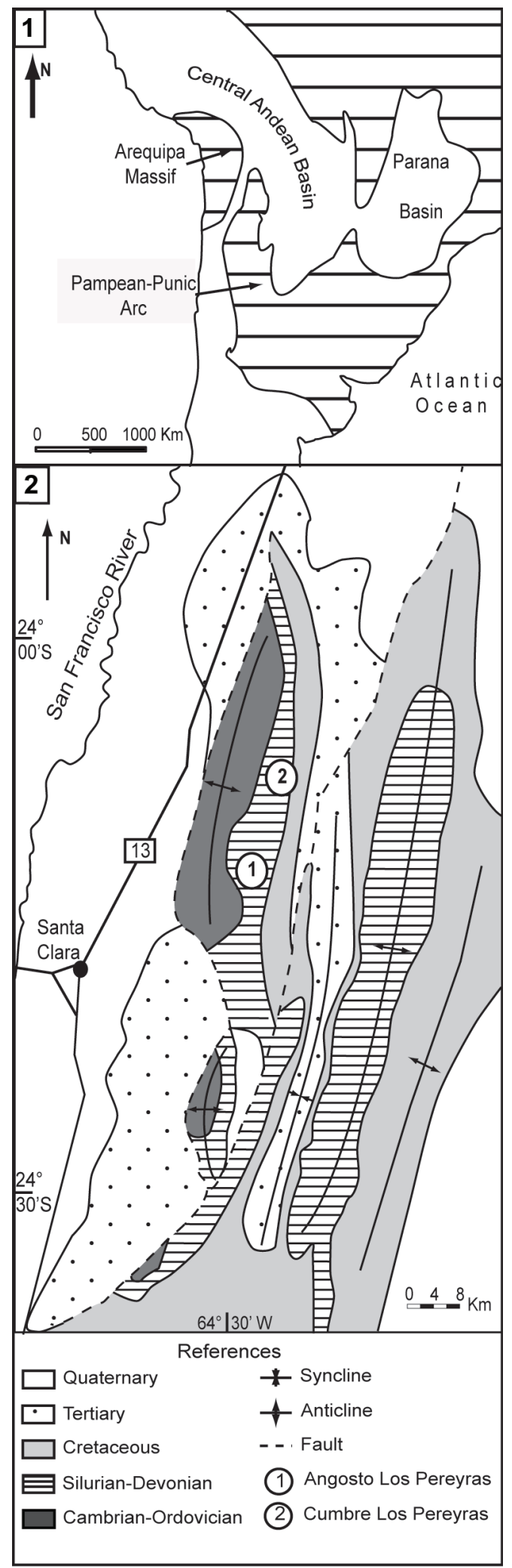

Cachipunco Formation (Padula et al., 1967) and Arroyo Colorado (Andreis et al., 1982).

Zapla Formation is composed mainly by argillaceous sandstones, which present disperse quartz clasts; sandstones and diamictits. It may reach up to $100 \mathrm{~m}$ in thickness and it was originally referred to the Llandoverian, based on stratigraphic correlation (Antelo, 1973; Cuerda \& Antelo, 1973). Notwithstanding, more recent works (Monaldi \& Boso, 1987; Astini et al., 2004; Rubinstein, 2005; de La Puente \& Rubinstein, 2007; Rubinstein et al., 2007) reassigned it to the Ordovician due to the finding of Dalmatina at the top of the unit. Lipeón Formation comprises a monotonous succession, between 600 and 1,600 metres in thickness, of siltstones and fossiliferous sandstones. According to Andreis et al. (1982), it formed in an extern marine platform, beneath the wave base level. Benedetto et al. (1992) gave this formation a Llandoverian-Pridolian age, but Rubinstein \& Toro (2006) assigned it to the Llandovery-Ludlow based on the palynomorphs and graptolites content.

The stratigraphy of Silurian-Devonian rocks in the Santa Bárbara range has been described in several publications (e.g., Padula et al., 1967; Mingramm \& Russo, 1972; Antelo, 1978; Mingramm et al., 1979; Moreno Espeleta et al., 1981; Pezzi \& Mozetic, 1990; Vistalli, 1990; Starck, 1995; Aceñolaza et al., 2000; Astini et al., 2004).

In outline, Cachipunco Formation comprises a succession of laminated black shales, rich in fossils and pyrite, interstratified with quarcitic sandstones. It is partially equivalent to Lipeon Formation, with a greater participation of sandstones. According to Mingramm et al. (1979) it would have been deposited in a sublitoral marine environment. This unit was proposed by Padula et al. (1967) grouping the "piso Z1" of Hagerman (1933) and Bellmann's "Gotlandico" (1962).

The fossil content of these rocks, mainly invertebrates and palynomorphs, has been extensively studied (Baldis, 1972; Antelo, 1978; Bultynck \& Martin, 1982; Sánchez, 1990; Rubinstein, 1997, 2003; Grahn \& Gutiérrez, 2001; Rubinstein \& Toro, 2006).

The aim of the present paper is to discuss the palynological content (acritarchs, prasinophyceaes and spores), from the Cachipunco Formation, in the Santa Bárbara range (South-eastern Jujuy Province; Fig. 1.2).

Fig. 1. 1, Map showing the location of the Silurian Central Andean Basin in South America (Modified from Benedetto et al., 1992). 2, Geological Map of Santa Barbara Range. 


\section{GEOLOGICAL SETTING AND BIOSTRATIGRAPHY}

The palynological samples were collected from two different sections both corresponding to the Cachipunco Formation: Angosto Los Pereyras and Cumbre Los Pereyras (Fig. 1.2). The area is located approximately $150 \mathrm{~km}$ to the Southeast of San Salvador de Jujuy, Jujuy Province.

\section{Angosto Los Pereyras}

Angosto Los Pereyras is located to the North of the Arroyo Colorado and to the East of Santa Clara City. At this location, Cachipunco Formation comprises 273 meters of micaceous, dark-grey to yellow siltstones without visible base or top (Fig. 2.1). These siltstones, which are bioturbated, are intercalated with thin beds of light-grey, micaceous, argillaceous fine sandstones

\section{Cumbre Los Pereyras}

This section is located near 8 kilometers to the north of Angosto Los Pereyras. It comprises 135 meters of siltstones and sandstones, of similar characteristics of those from Angosto Los Pereyras, but with a larger proportion of sandstones than in the latter (Fig. 2.2).

\section{Biostratigraphy}

Cachipunco Formation was originally referred to the Early Devonian due to the presence of macrofloristic remains (see Padula et al., 1967, Mingramm et al., 1979). Subsequently, was transferred to the Middle-Late Silurian (Baldis, 1972; Antelo, 1978; Vistalli, 1990), and more recently, Grahn \& Gutiérrez (2001), assigned it a Late Llandoverian Early Pridolian age, based on the analysis of the chitinozoa content of the unit.

\section{MATERIALS AND METHODS}

Forty palynological samples were collected from the Cachipunco Formation, 30 of which were found to be productive. Samples were processed using palynological HCl-HF-HCl acid maceration techniques (see Wood et al., 1996). Slides were examined using light microscopy and scanning electronic microscopy.

Light photomicrographs were taken on an Olympus BX-51 microscope using an Olympus C-5000 digital camera, while the scanning micrographs were taken on Philips XL-30 at 20 $\mathrm{kV}$. All figured material is housed in the collection of the MACN (Museo Argentino de Ciencias Naturales "B. Rivadavia") under the prefixes BA
Pal (Buenos Aires, Palynology). The specimen locations are referred using England Finder coordinates.

The preservation state of the material is quite bad, being the majority of specimens fragmented, often impregnated with pyrite and most of them showing signs of corrosion. Such situation made difficult the assignment of same palynomorphs.

For identification purposes, different measures were taken, as referred on the systematic section. Abbreviations of such measures are as follows: $\mathrm{V} \varnothing=$ Diameter of the vesicle; $\mathrm{VW}=$ Width of the vesicle; VL = Length of the vesicle; VT $=$ Total length of the vesicle (including processes); PL = Length of the processes; PN $=$ Number of processes; $\mathrm{P} \varnothing=$ Diameter of the processes; $\mathrm{P} \varnothing \mathrm{B}=$ Diameter of the bases of the processes; $\mathrm{P} \varnothing \mathrm{D}=$ Diameter of the distal end of the processes; $\mathrm{PL} / \mathrm{V} \varnothing=$ Length of the processes/ vesicle diameter ratio; VW/VL = Vesicle width/ vesicle length ratio; VW/VT = Vesicle width/vesicle total length ratio; $\varnothing=$ Diameter (for spores); $\mathrm{Cw}=$ Cingule width; $\mathrm{Zw}=$ Zone width. Such measures are presented in the format N1 (N2) $\mathrm{N} 3$, where N1 and N3 represent the minimum and the maximum value measured respectively, and N2 the mean for all the specimens evaluated. The number of specimens measured appears between brackets. In the Synonym and Distribution sections it is included primarily the material described for Argentina. For the graphic showing vertical and percentage distributions (Figs. 3 and 4) there where counted between 200 and 300 palynomorphs per slide.

\section{SYSTEMATICS}

\section{Group ACRITARCHA Evitt 1963}

Genus Ammonidium Lister 1970

Type species: Ammonidium microcladum (Downie) Lister 1970.

Ammonidium ludloviense (Lister) Dorning 1981 (Fig. 3.1)

1987 Ammonidium rigidum (aff.) var. ludloviense Lister; Pöthe de Baldis: 90, pl. I, fig. 1.

1993 Ammonidium rigidum var. ludloviense Lister; Rubinstein: 70.

1998 Ammonidium waldronense (Tappan \& Loeblich) Dorning; Pöthe de Baldis: 6, pl. I, figs. 7-8.

Dimensions. $\mathrm{V} \varnothing=20(25) 30 \mu \mathrm{m}, \mathrm{PL}=4(5) 6$ $\mu \mathrm{m}, \mathrm{P} \varnothing \mathrm{B}=2 \mu \mathrm{m}, \mathrm{P} \varnothing \mathrm{D}=1 \mu \mathrm{m}, \mathrm{PL} / \mathrm{V} \varnothing=0.2$, Eylima, $0.5 \mu \mathrm{m}$ (2 specimens measured). 


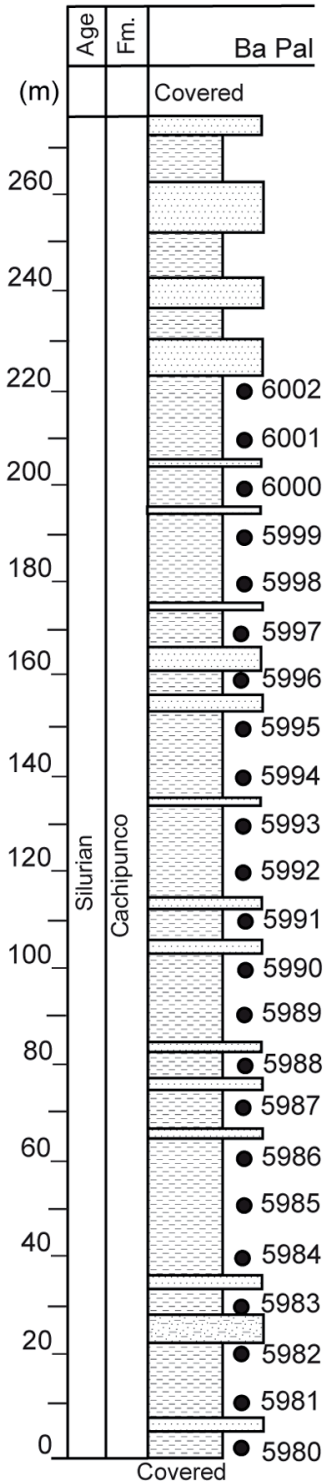

\section{Angosto Los Pereyras Section}

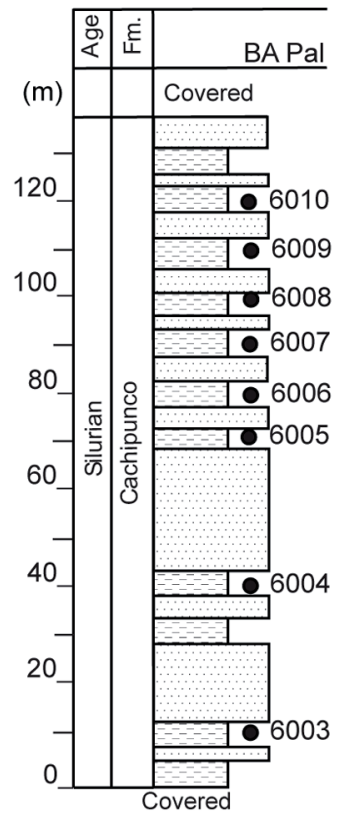

2. Cumbre Los Pereyras Section

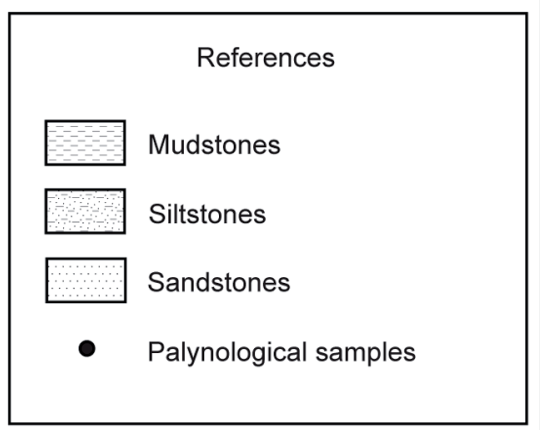

Fig. 2. Schematic stratigraphical logs of Angosto Los Pereyras and Cumbre Los Pereyras.

Remarks. Ammonidium rigidum (Deunff) var. ludloviense Lister as described and illustrated by Pöthe de Baldis (1987) it corresponds to the species described here due to the length and shape of its processes and the vesicle diameter. The specimen described by Pöthe de Baldis (1998) as A. waldronense (Tappan \& Loeblich) Dorning is here reassigned to $A$. ludloviense owing to the length of its processes $(3.5 \mu \mathrm{m})$. According to Tappan \& Loeblich (1971) the length for A. waldronensis processes is between $5-10 \mu \mathrm{m}$.
Ammonidium sp. cf. A. waldronense

(Tappan \& Loeblich) Dorning 1981

(Fig. 3.2)

1987 Caiacorymbifer cf. waldronis Tappan \& Loeblich; Pöthe de Baldis: pl. 1, fig. 8.

Description. Vesicle spherical, hollow, singlewalled. Eylima thin $(0.5 \mathrm{~mm})$. Numerous processes (near 30 visible), hollow and freely communicated with the vesicle interior. Processes 
tapered into distally equifurcate terminations. No excystment method observed.

Dimensions. $\mathrm{V} \varnothing=22(24.5) 27 \mu \mathrm{m}, \mathrm{PL}=8(9) 10$ $\mu \mathrm{m}, \mathrm{P} \varnothing \mathrm{B}=1.5-2 \mu \mathrm{m}, \mathrm{P} \varnothing \mathrm{D}=1 \mu \mathrm{m}, \mathrm{PL} / \mathrm{V} \varnothing=$ $0.3(0.37) 0.4$ (5 specimens measured).

Remarks. These specimens are assigned to Ammonidium cf. waldronense (Tappan \& Loeblich) Dorning since the number of processes is not as high as it is in the holotype (more than 40; Tappan \& Loebliech, 1971) and no assessment of the vesicle ornamentation can be made due to the bad preservation state of the material. The material illustrated by Pöthe de Baldis (1987) as Caiacorymbifer cf. waldronis (sic) might be considered to be co-specific with the one described here, based on the processes characteristics and the relationship processes length/vesicle diameter (0.37 in Pöthe de Baldis 1987).

\section{Ammonidium sp. A}

(Fig. 3.3)

Description. Vesicle spherical, hollow, with few (between 3-7), hollow, open-to-vesicle-interior, slightly tapering processes. Processes equifurcate distally into 3-5 spines. No excystment method observed.

Dimensions. VØ $=22(24) 26 \mu \mathrm{m}, \mathrm{PL}=12(16) 20$ $\mu \mathrm{m}, \mathrm{P} \emptyset \mathrm{B}=2 \mu \mathrm{m}$ ( 2 specimens measured).

Remarks. Owing to the ramification pattern that presents this specimen, we assigned it to the genus Ammonidium. A more accurate assignment could not be made due to the bad preservation of the material.

Genus Barathrisphaeridium Wicander 1974

Type species: Barathrisphaeridium chagrinense Wicander 1974.

\section{Barathrisphaeridium? sp. A}

(Fig. 3.4)

Description. Vesicle spherical in outline, evenly covered with numerous (near 25) slender, flexible, relatively short, homomorphic, and acuminated processes. Processes are solid and do not communicate with vesicle interior. Excystment by rupture of the vesicle wall.

Dimensions. $\mathrm{V} \varnothing=25(28.3) 33 \mu \mathrm{m}, \mathrm{PL}=$ 7(9.6)13 $\mu \mathrm{m}, \mathrm{P} \varnothing \mathrm{B}=1(1.2) 2 \mu \mathrm{m}, \mathrm{P} \varnothing \mathrm{D}=0.5 \mu \mathrm{m}$ (7 specimens measured).

Remarks. The bad state of preservation of the material does not allow the nature of the wall structure to be observed; therefore the species are doubtfully assigned to this genus. The specimens described by Rubinstein for

Los Espejos Formation (Rubinstein, 1992b) as Barathrisphaeridium? sp. have significantly shorter processes.

Genus Barbestiastra Sarjeant \& Stancliff 1994

Type species: Barbestiastra barbata (Downie) Sarjeant \& Stancliffe 1994.

Barbestiastra barbata (Downie) Sarjeant \& Stancliffe 1994

(Figs. 3.5, 7.5)

1971 Estiastra cf. barbata Downie; Pöthe de Baldis: 286, pl. 1, fig. 7.

1975a Estiastra aff. barbata Downie; Pöthe de Baldis: 494, pl. V, figs. 2, 5.

Dimensions. $\mathrm{T}=77(87.25) 94 \mu \mathrm{m}, \mathrm{PL}=$ $20(25) 31 \mu \mathrm{m}$; 8 to 10 conical processes (4 specimens measured).

Remarks. The material described by Pöthe de Baldis (1971, 1975a) and doubtfully assigned to Estiastra barbata Downie is considered to be co specific with the specimens characterized here because both of them display similar features, in shape and ornamentation patterns.

Genus Cymbosphaeridium Lister 1970

Type species: Cymbosphaeridium bikidum Lister 1970.

\section{Cymbosphaeridium sp. A}

(Fig. 3.7)

Description. Vesicle roughly spherical, darkcoloured, probably double-walled, with 10 transparent, hollow, columnar, flexible processes. Distal ends are open and present aculeate tips. No excystment method observed.

Dimensions. $\mathrm{V} \varnothing=47 \mu \mathrm{m}, \mathrm{P} \emptyset=4-6 \mu \mathrm{m}, \mathrm{PL}=$ $17 \mu \mathrm{m}, \mathrm{PN}=7$ ( 1 specimen measured).

Remarks. Cymbosphaeridium pilar (Cramer) Lister (1970) has a granulate vesicle and cauliflorate branching at the tips.

Genus Diexallophasis Loeblich emend. Sarjeant \& Vavrdová 1997

Type species: Diexallophasis remota (Deunff) Playford 1977. 
Diexallophasis denticulata (Stockmans \& Willière) Loeblich 1970

(Fig. 3.118)

1997a Diexallophasis cf. remota (Deunff) Playford; Pöthe de Baldis: 41, pl. II, fig. 5.

?1997 Evittia denticulata denticulata (Cramer) Le Hérissé; Rubinstein: 164, pl. 7, fig. 11.

1997b Diexallophasis remota (Deunff) Playford; Pöthe de Baldis: 468, pl. I, fig. 15.

Dimensions. $\mathrm{V} \varnothing=21(29.1) 35 \mu \mathrm{m}, \mathrm{PL}=$ 18(25.7)32 $\mu \mathrm{m}, \mathrm{P} \varnothing \mathrm{B}=4(4.6) 6 \mu \mathrm{m}, \mathrm{P} \varnothing \mathrm{D}=$ 1(1.4) $2 \mu \mathrm{m}$ (26 specimens measured).

Remarks. Specimens observed here present different degrees of deformation due to folds in its wall. Diexallophasis denticulata and D. remota (Deunff) Playford (1977) have been considered by several authors (Playford, 1977; Sarjeant \& Vavrdova, 1997) to be synonyms. Mullins (2002) maintained them as separated species, hinged on the characteristics of the processes, being broader-based and more robust in $D$ remota, and the ornamentation of the vesicle, which is micropuntuate to foveolate in $D$. denticulata. Additionally to this, we consider $D$. remota to have a distinct sub polygonal vesicle, and more processes than $D$. denticulata. Therefore, we consider them to be different species.

The specimens described as $D$. cf. remota (Deunff) Playford by Pöthe de Baldis (1997a), clearly presents all the distinct characteristics of $D$. denticulata, a globular vesicle with few processes arising from it, so we reassign them herein. In the same way, the material illustrated by Pöthe de Baldis (1997b), depict similar characteristics to those of $D$. denticulata, a spherical vesicle, with 4-5 long processes, and therefore is reassigned to that species. Probably, the material described by Rubinstein (1997) as Evittia denticulata denticulata (Cramer) Le Hérissé, also corresponds to $D$. denticulata, since both preset similar vesicle and processes characteristics.

\section{Diexallophasis remota (Deunff) Playford 1977 \\ (Fig. 3.8)}

Dimensions. $\mathrm{V} \varnothing=22(28.2) 36 \mu \mathrm{m}, \mathrm{PL}=$ 20(27.7) $37 \mu \mathrm{m}, \mathrm{P} \varnothing \mathrm{B}=3(3.9) 5 \mu \mathrm{m}, \mathrm{P} \varnothing \mathrm{D}=0.5$ $1.5 \mu \mathrm{m} ; 7-13$ processes (20 specimens measured).

Remarks. Diexallophasis denticulata (Stockmans \& Willière) Loeblich (1970) has lesser processes and a subspherical vesicle. Diexallophasis downtongorgensis Mullins (2004) has a smaller spherical vesicle with 4-7 processes.

\section{Diexallophasis sp. A}

(Figs. 3.9, 7.1)

2000 Exochoderma? sp. aff. E. arca Wicander \& Wood; Pöthe de Baldis: 332, pl. 3, fig. $\mathrm{H}$.

Description. Vesicle quadrangular in outline, with straight sides. Eylima single-layered, laevigate to slightly granulate. One process developed at each corner, and one arising from the centre face of vesicle. Processes (4-6 in total) are hollow and communicate freely with the vesicle interior. They are ornamented with grana or small spines, and very lightly costate. Distally ended in a simple, closed, pointed tip. Some processes are truncated. Excystment method not observed.

Dimensions. $\mathrm{V} \varnothing=24(28) 31 \mu \mathrm{m}, \mathrm{PL}=16(26) 34$ $\mu \mathrm{m}, \mathrm{PN}=5-7, \mathrm{P} \varnothing \mathrm{B}=5(5.3) 7 \mu \mathrm{m}, \mathrm{P} \varnothing \mathrm{D}=1(1.4) 2$ $\mu \mathrm{m}$ (16 specimens measured).

Remarks. The material described by Pöthe de Baldis (2000: Exochoderma sp. aff. E. arca Wicander \& Wood) for Los Espejos Formation is considered to be co-specific with Diexallophasis sp. A since both have the same characteristics (similar vesicle length, equal number of processes and similar processes length). Both are differentiated from Exochoderma arca Wicander \& Wood (1981), as the latter is larger and has most process bifurcated. Diexallophasis sp A is differentiate from $D$. denticulata due to the vesicle shape (being in the former much more polygonal than in the latter), to the presence of ridges in the base of the processes and the fact that distal ends in this species are acuminated and do not show any type of bifurcation. Diexallophasis remota is separated from $D$. sp A. based on this species has a quadrangular vesicle, with lesser processes (up to 6) than D. remota.

Diexallophasis mucronata (Stockmans \& Willière) Priewalder has a smaller vesicle and its processes present a distinct pattern of branching (Stockmans \& Willière, 1963; Priewalder, 1987). It differs from $D$. downtongorgensis Mullins (2004) in having a larger vesicle, more notorious ornamentation and the same wall thickness in both, vesicle and processes.

Genus Domasia Downie emend. Hill 1974

Type species: Domasia trispinosa Downie emend. Hill 1974. 

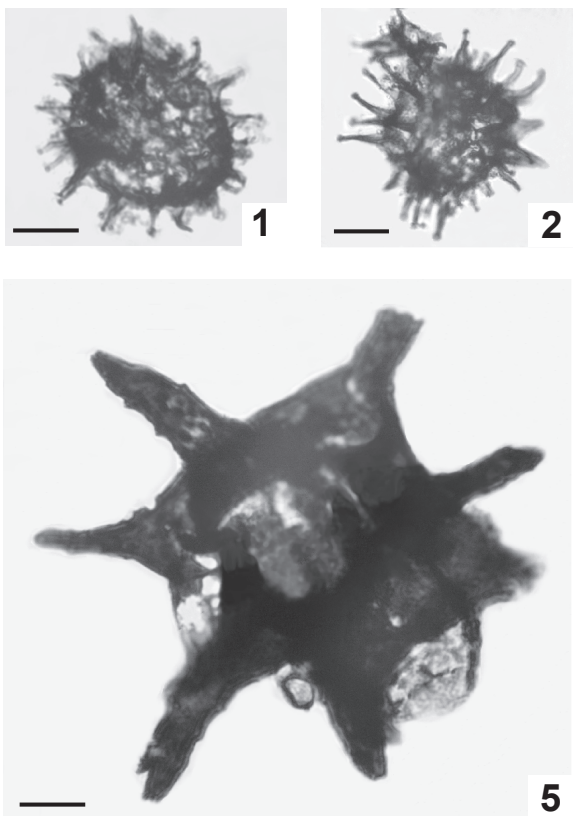

5

5

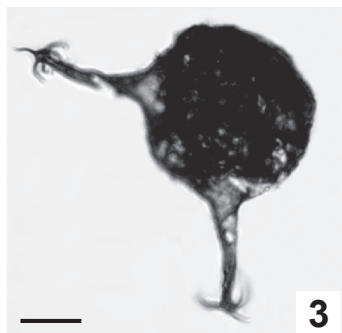

3

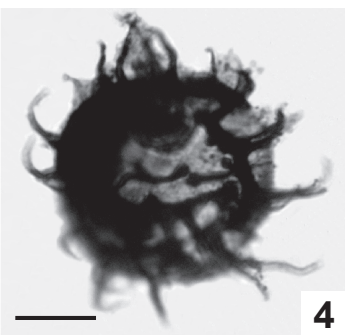

4
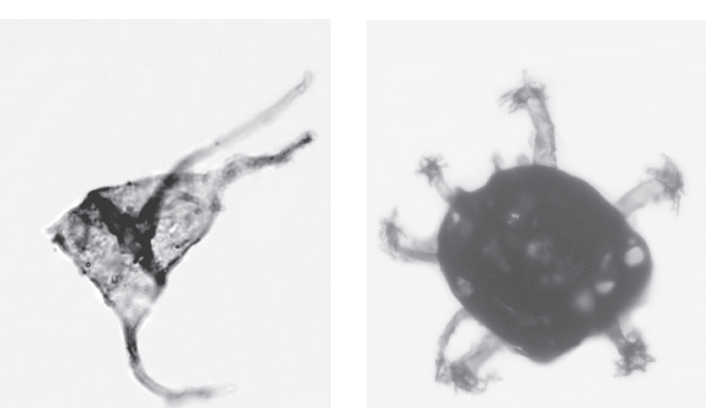

6

7
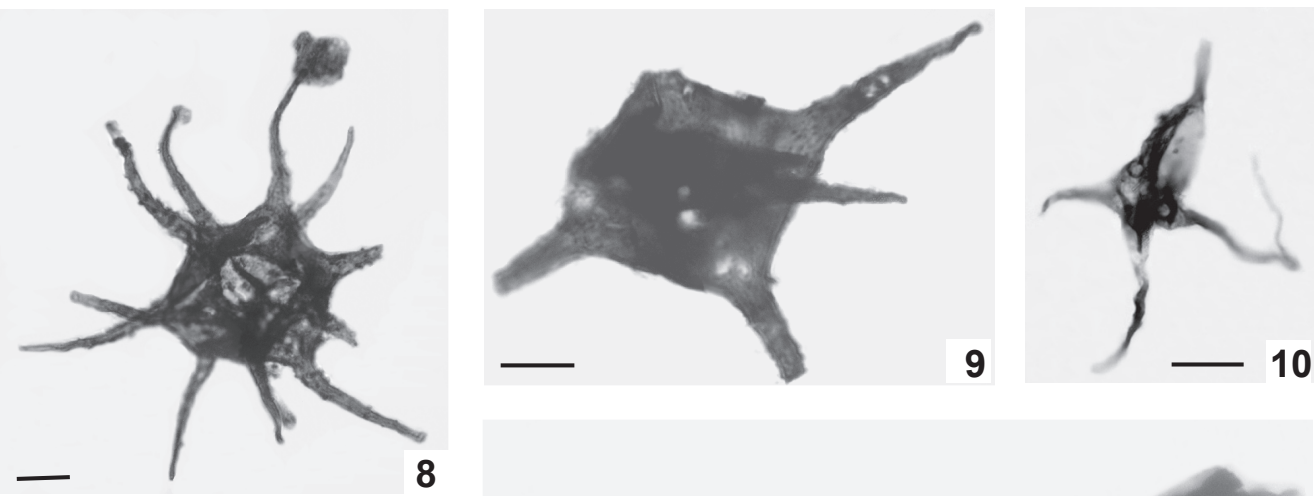

8
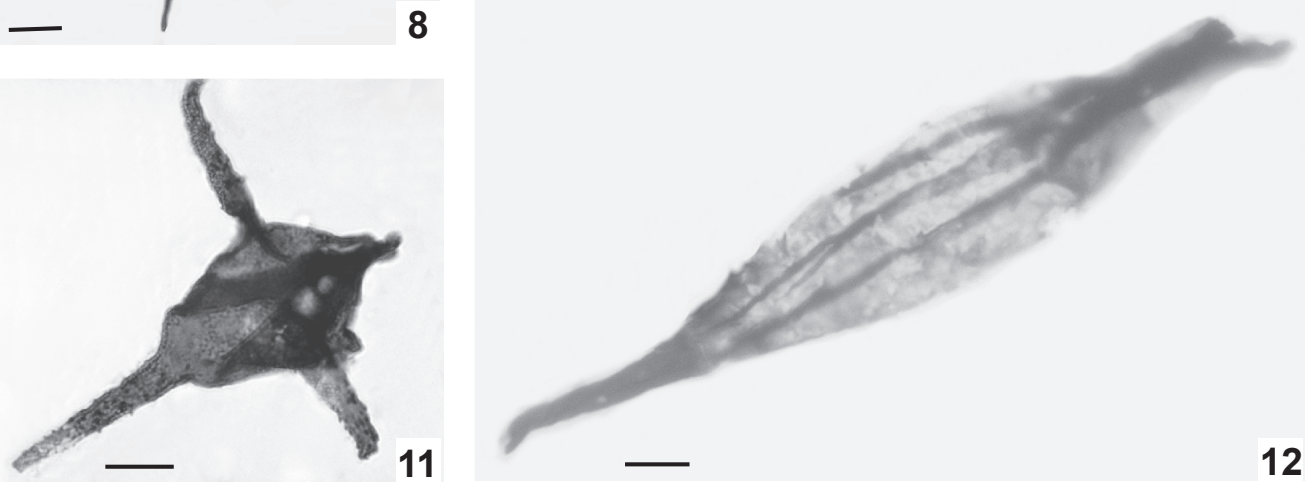

Fig. 3. 1, Ammonidium ludloviense (Lister) Dorning 1981, BA Pal 6005(1) D30/3. 2, Ammonidium sp. cf. A. waldronense (Tappan \& Loeblich) Dorning 1981, BA Pal 5981 W54/0. 3, Ammonidium sp. A, BA Pal 5988(1) G37/2. 4, Barathrisphaeridium? sp. A, BA Pal 5992(1) Q49/0. 5, Barbestiastra barbata (Downie) Sarjeant \& Stancliffe 1994, BA Pal 5992(3) Z57/1. 6, Dorsennidium europaeum (Stockmans \& Willièire) Sarjeant \& Stancliffe 1994, BA Pal 5988(1) K41/3. 7, Cymbosphaeridium sp. A, BA Pal 5986(2) S62/4 [x0.3]. 8, Diexallophasis remota (Deunff) Playford 1977, BA Pal 5988(1) J51/3. 9, Diexallophasis sp. A, BA Pal 5981(1) E61/4. 10, Domasia quadrispinosa Hill 1974 (Pl. 2, fig. B), BA Pal 5988(1) S55/0. 11, Diexallophasis denticulata (Stockmans \& Willière) Loeblich 1970, BA Pal 5988(2) G45/0. 12, Eupoikilofusa filifera (Downie) Dorning 1981, BA Pal 5986(2) F56/2 [x0.5]. 


\section{Domasia quadrispinosa Hill 1974}

(Fig. 3.10)

Dimensions. $\mathrm{V} \varnothing=17(20.5) 22 \mu \mathrm{m}, \mathrm{PL}=$ 17(21.7)30 $\mu \mathrm{m}$ (4 specimens measured).

Remarks. We differentiate this species from Dorsennidium europaeum (Stockmans \& Willièire) Sarjeant \& Stancliffe due to the nature of its vesicle (Stockmans \& Willièire, 1960; Sarjeant \& Stancliffe, 1994). In D. quadrispinosa Hill, the vesicle is elongated and inflated, while in $D$. europeaum the vesicle is triangular and flattened.

Genus Dorsennidium Wicander emend. Sarjeant \& Stancliffe 1994

Type species: Dorsennidium patulum Wicander 1974.

Dorsennidum europaeum (Stockmans \& Willièire) Sarjeant \& Stancliffe 1994 (Fig. 3.6)

Dimensions. VØ $=12 \mu \mathrm{m}, \mathrm{PL}=20 \mu \mathrm{m}, \mathrm{P} \emptyset \mathrm{B}=$ $2 \mu \mathrm{m}$ (1 specimen measured).

\section{Genus Eupoikilofusa Cramer 1970a}

Type species: Leiofusa striatifera (Cramer) Cramer 1970a.

Remarks. The validity of the name Eupoikilofusa, as discussed on Dorning (1994), is accepted here.

\section{Eupoikilofusa filifera (Downie) Dorning emend. Mullins 2001}

(Fig. 3.12)

1971 Leiofusa argentina Pöthe de Baldis: 287, pl. I, fig. 1.

1981 Eupoikilofusa argentina (Pöthe de Baldis) Pöthe de Baldis: 239, pl. V, fig. 2.

1987 Leiofusa argentina Pöthe de Baldis; Priewalder: 87.

1990 Leiofusa cf. striata Brito \& Santos; Rubinstein: 91, pl. II, fig. 11.

1992a Leiofusa cf. striata Brito \& Santos; Rubinstein: 244-245.

1993 Leiofusa filifera Downie, Rubinstein: 71.

1997a Dactylofusa cf. argentina (Pöthe de Baldis) Pöthe de Baldis: 39, pl. I, fig. 5.

1997 Dactylofusa striatifera (Cramer) Fensome et al.; Rubinstein: 164, pl. I, fig. 5.

Dimensions. VW $=23(24.8) 25 \mu \mathrm{m}, \mathrm{VT}=$ $120(132) 150 \mu \mathrm{m}$ (6 specimens measured).
Remarks. Almost all specimens are incomplete. According to Fensome et al. (1990) Eupoikilofusa filifera is an invalid combination and it must be referred to Dactylofusa filifera (Downie) Fensome et al. (1990), however Dorning (1994) made a revision of these generas maintaining as a valid genera Eupoikilofusa. The differentiation between $E$. sriatifera and $E$. filifera is based on the number and general characteristics of their striaes. In the first one, striaes appear in a large number, being them thin and discontinuous, while in the second one, the striaes are thick, continuous and there are only between 2 to 5 of them in each individual.

In conformity with this, Leiofusa argentina Pöthe de Baldis (1971) is a junior synonym of $E$. filifera not of $E$. striatifera as stated by Priewalder (1987). The material described by Rubinstein (1990), and classified as L. cf. striata Britos \& Santos, could be reubicated as E. filifera due to the number (2-4) and characteristics of the striations seen on the illustration of that specimen. The material from La Horqueta Formation categorized as Dactylofusa striatifera (Cramer) Fensome et al. (Rubinstein, 1997) seem to be $E$. filifera (Downie) Dorning, due to the number of the striations (4) that can be seen in the illustration.

\section{Eupoikilofusa striatifera (Cramer) Cramer 1970}

(Fig. 4.1)

1975a Leiofusa aff. striatifera Cramer; Pöthe de Baldis: 494, pl. III, fig. 9.

1990 Eupoikilofusa cf. striatifera-complex Cramer \& Diez; Rubinstein: 88, figs. 2-3.

1997b Dactylofusa striatifera (Cramer) Fensome et al.; Pöthe de Baldis: 468, pl. IV, fig. 11.

Dimensions. VW $=20(23.5) 28 \mu \mathrm{m}, \mathrm{VT}=$ 128(141.7) $150 \mu \mathrm{m}$ (10 specimens measured).

Remarks. Eupoikilofusa striatifera (Cramer) Cramer 1970 differs from $E$. filifera Downie (1959) in the number of striations they have. The latter has between 2 and 5 , while the former has 8 or more. Leiofusa estrecha Cramer (1964a) is similar in size to $E$. striatifera but the former has a psilated eylima.

Eupoikilofusa sp. cf. E. tenuistriata (Pöthe de Baldis) Pöthe de Baldis 1981

(Fig. 4.2)

Description. Vesicle hollow, fusiform with one side convex and the other side straight to slightly 
concave. A short process arises from each pole of the vesicle. Processes are hollow, open to vesicle cavity and simple. They are preferentially displaced to the straighter side of the vesicle. No excystment method observed.

Dimensions. VL $=53(56) 60 \mu \mathrm{m}, \mathrm{VW}=$ 23(23.5) $24 \mu \mathrm{m}, \mathrm{PL}=28(29) 30 \mu \mathrm{m}$ (2 specimens measured).

Remarks. The striations on the surface of the vesicle of this species are inconspicuous due to the preservational state of the material. As a result of that, a more accurate assignation is impossible to be made. Eupoikilofusa cf. tenuistriata (Pöthe de Baldis) Pöthe de Baldis (1981) is similar in shape and dimension to the specimens described here, but in that case, striations present small grana regullary placed on them. Eupoikilofusa striatifera Cramer (1964a) differs in having a larger vesicle and more notorious striations, and $E$. filifera Downie (1959) has fewer striations and is larger. Leiofusa estrecha Cramer (1964a) differs in having a vesicle with two convex sides and a not ornamented wall. Dactylofusa cantabrica Cramer emend. Fensome et al. (1990) is similar is size and shape to this specimen, but differs in its ornamentation being fossulate instead of striated (Cramer, 1964a).

Genus Gorgonisphaeridium Staplin et al. emend. Kiryanov 1978

Type species: Gorgonisphaeridium winslowlii Staplin et al. 1965.

\section{Gorgonisphaeridium sp. cf. G. succinum Lister 1970}

(Fig. 4.3)

Description. Vesicle hollow, spherical, evenly covered with relatively short, tapering, flexible processes. Processes apparently solid, closed to vesicle interior, acuminated or bifurcated up to the second order. No excystment structure observed.

Dimensions. $\mathrm{V} \varnothing=23(27.6) 32 \mu \mathrm{m}, \mathrm{PN}=$ 15(21)30, PL = 5(8)11 $\mu \mathrm{m}, \mathrm{P} \varnothing \mathrm{B}=1(1.2) 2 \mu \mathrm{m}$, $\mathrm{PL} / \mathrm{V} \varnothing=0.2(0.3) 0.4$ (26 specimens measured).

Remarks. The bad state of preservation in which the material is found prevents from identifying some of the distinctive characteristics of the species, especially those concerning vesicle ornamentation and wall thickness. Gorgonisphaeridium? listeri forma listeri Mullins (2001) is similar in size to $G$. sp. cf. $G$. succinum Lister, but differs from it in processes length (in the former are shorter, between 1-6 $\mu \mathrm{m}$ ) and branching pattern (in G. listeri forma listeri processes are acuminated or showing distal branching). Gorgonisphaeridium citrinum Downie emend. Mullins (2001) has shorter processes (around 0.7-3 $\mu \mathrm{m}$ ); and G. spinosum Pöthe de Baldis (1974) is differentiate from $G$. sp. cf. G. succinum found on the base-width of their processes -being wider in the first one- an overall smaller size $(20-22 \mu \mathrm{m})$, and the fact that $G$ spinosum show only one order of ramification.

Genus Leiofusa Eisenack emend. Cramer 1970

Type species: Leiofusa fusiformis (Eisenack) Eisenack 1938.

\section{Leiofusa bernesgae Cramer 1964a}

(Figs. 4.5, 7.6)

1965 Leiofusa bispinosoides Britos \& Santos: 10-11, 18, pl. 1 , fig. 8 .

1971 Leiofusa banderilla (sic) Cramer; Pöthe de Baldis: 287, pl. I, fig. 6.

1975a Leiofusa cf. bernesgae Cramer; Pöthe de Baldis: 493, pl. III, figs. 1-2, 4.

1990 Leiofusa cf. bernesgae Cramer; Rubinstein: 90, pl. I, figs. 13-14, 17.

Dimensions. VL $=24(26.3) 30 \mu \mathrm{m}, \mathrm{VW}=$ 12(16.8) $20 \mu \mathrm{m}, \mathrm{VT}=69(106) 144 \mu \mathrm{m}, \mathrm{PL}=$ $24(40.1) 62 \mu \mathrm{m}, \mathrm{VW} / \mathrm{VL}=0.57(0.69) 0.87$ (6 specimens measured).

Remarks. Leiofusa bispinosoides Brito \& Santos (1965) is considered to be a junior synonym of $L$. bernesgae by Moreau-Benoit (1974). The differences in size of the material described by Pöthe de Baldis (1975a) and Rubinstein (1990) are not enough criteria to separate these materials from $L$. bernesgae, as stated also by Rubinstein (1992b). Leiofusa "banderilla" Cramer, described by Pöthe de Baldis (1971), showed all the distinctive characteristics (shape and size of the vesicle, length of the processes) of $L$. bernesgae, consequently it becomes reassigned here. Leiofusa banderillae Cramer (Pöthe de Baldis, 1987) has the appearance of being a specimen of $L$. bernesgae, but both processes are broken, making such designation impossible. The original material of L. banderillae Cramer (1964a) has longer processes (between 100-150 $\mu \mathrm{m}$ ).

\section{Leiofusa estrecha Cramer 1964a}

(Fig. 4.4)

Dimensions. VT $=120(158.3) 225 \mu \mathrm{m}, \mathrm{VW}=$ $25(26) 35 \mu \mathrm{m}, \mathrm{VW} / \mathrm{VT}=0.11(0.17) 0.28(8$ specimens measured). 
Remarks. All specimens are incomplete. Leiofusa fusiformis Eisenack (1934) presents a pilome and a different shape of the processes; $L$. parvitatis Loeblich (1970) is smaller (the overall length varies from 50 to $93 \mu \mathrm{m})$. Eupoikilofusa filifera (Downie) Dorning (1981) and E. striatifera (Cramer) Cramer (1970a) are similar in size, but both present striations (or folds) on their surface. Eupoikilofusa tenuistriata (Pöthe de Baldis) Pöthe de Baldis (1981) presents subtle striations on its wall and has a different vesicle shape.

\section{Leiofusa exilata Dorning 1981}

(Fig. 4.6)

Dimensions. VW $=13(14.7) 18 \mu \mathrm{m}, \mathrm{VT}=$ 100(184.3)263 $\mu \mathrm{m}, \mathrm{VW} / \mathrm{VT}=0.05(0.10) 0.18(3$ specimens measured).

Remarks. Despite the fact that Leiofusa exilata Dorning (1981) is smaller in width than the specimens described here, we assigned it to this species based on the similarities both share in length, general shape and relation: vesicle width/ total length. Leiofusa exilata is also similar in size to L. estrecha Cramer (1964a), differing from it the overall shape and the width/total length relationship.

\section{Leiofusa parvitatis Loeblich 1970}

(Fig. 4.11)

Dimensions. $\mathrm{VL}=19(21) 24 \mu \mathrm{m}, \mathrm{VW}=9(9.8) 12$ $\mu \mathrm{m}, \mathrm{PL}=18(29.3) 40 \mu \mathrm{m}, \mathrm{VT}=57(79.5) 104 \mu \mathrm{m}$, $\mathrm{VW} / \mathrm{VL}=0.4-0.5$ (4 specimens measured).

Remarks. Leiofusa estrecha Cramer (1964a) is larger (overall length varies between 120-400 $\mu \mathrm{m})$. Eupoikilofusa filifera (Downie) Dorning (1981) is also larger and displays between 3-5 thickenings on its surface.

\section{Leiofusa tumida Downie 1959}

(Fig. 4.7)

1990 Leiofusa cf. tumida Downie; Rubinstein: 91, pl. II, fig. 9.

Dimensions. VL $=20(23) 25 \mu \mathrm{m}, \mathrm{VW}=14(16.2) 20$ $\mu \mathrm{m}, \mathrm{PL}=34(40) 50 \mu \mathrm{m}, \mathrm{VT}=95(103) 125 \mu \mathrm{m}, \mathrm{VW} /$ $\mathrm{VL}=0.7-0.8$ ( 3 specimens measured).

Remarks. Leiofusa cf. tumida Downie as described by Rubinstein (1990) is smaller (total length is $60 \mu \mathrm{m}$ ), but the difference in size is not enough criterions to substantiate its separation.

\section{Leiofusa sp. A}

(Fig. 4.8)

1975a Leiofusa aff. estrecha Cramer; Pöthe de Baldis: 494, pl. III, figs. $3,7$.

1981 Leiofusa banderillae Cramer, Pöthe de Baldis: 244 , pl. V, fig. 8.

1990 Leiofusa sp. A Rubinstein: 91, pl. I, fig. 15.

1997a Leiofusa tumida Downie; Pöthe de Baldis: 46, pl. I, fig. 17.

1998 Leiofusa bernesgae Cramer; Pöthe de Baldis: 10, pl. 3, fig. 7.

Description. Vesicle slightly rectangular, elongated with a process at each pole. Processes are solid and the contact process-vesicle is indistinct. Eylima thin and laevigated. No excystment method observed.

Dimensions. VL $=30(33) 36 \mu \mathrm{m}, \mathrm{VW}=7 \mu \mathrm{m}$, $\mathrm{VW} / \mathrm{VL}=0.23-0.19$ ( 2 specimens measured).

Remarks. In all the observed individuals processes were broken, making a more accurate assignation impossible. The specimens illustrated by Pöthe de Baldis (1975a, 1981, 1997a, 1998) as Leiofusa aff. estrecha, L. banderillae, L. tumida, and $L$. bernesgae respectively, display all the characteristics of the species described here. Leiofusa sp. A differs from L. bernesgae Cramer (1964a) and L. tumida Downie (1959) in the shape of the vesicle (which is cylindrical to rectangular in the former) and the nature of its processes (which are solid). It can be distinguished from $L$. estrecha based on its size (being the latter much larger, with overall lenghts that varies from 120 to $400 \mu \mathrm{m}$ ) and from L. banderillae Cramer (1964a) contrasting the length (around 100-150 $\mu \mathrm{m}$ ) and nature of the processes, as well as the shape of the vesicle.

Genus Micrhystridium Deflandre emend. Sarjeant \& Stancliffe 1994

Type species: Micrhystridium inconspicuum Deflandre 1935.

\section{Micrhystridium sp. cf. M. stellatum \\ Deflandre 1945 \\ (Fig. 4.10)}

Description. Vesicle originally spherical, but polyhedral in shape, bearing numerous (12-20) simple spines. Spines are slender, hollow and communicate freely with the vesicle cavity. Distal tips are simple and closed. Processes bases are wide, which gives the polyhedral shape in compression. Eylima laevigate and thin. No excyst- 

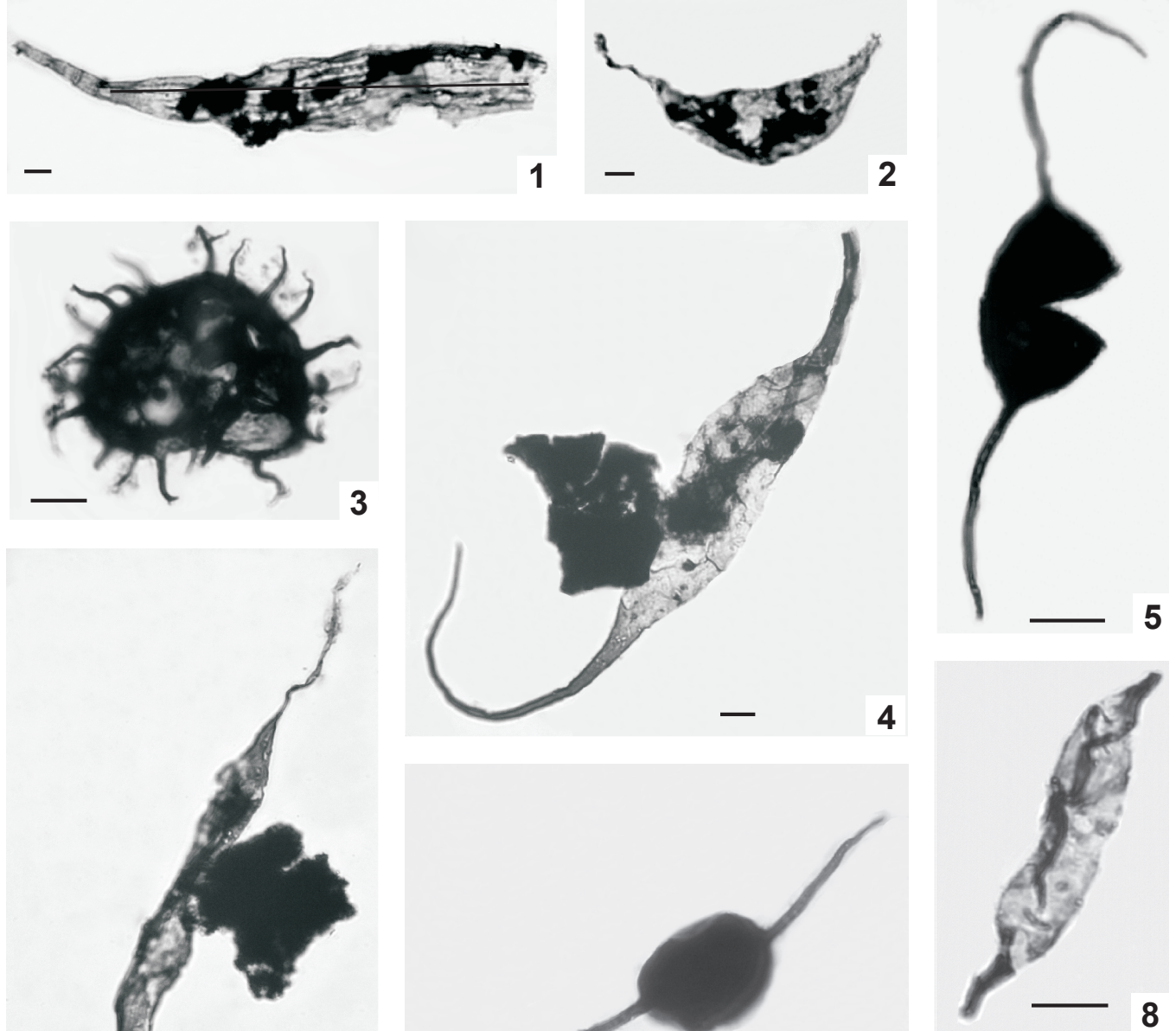

6

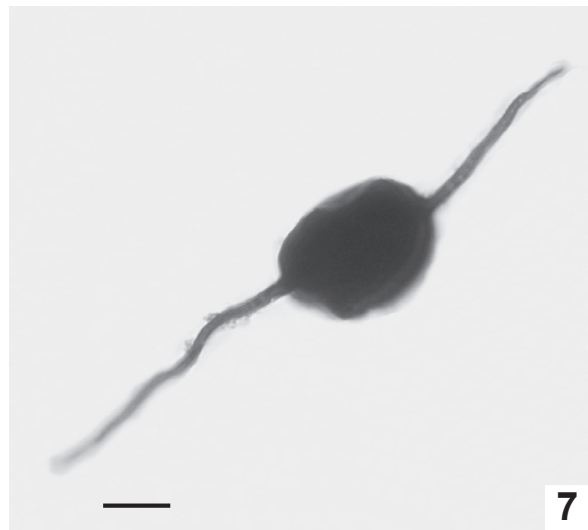

7

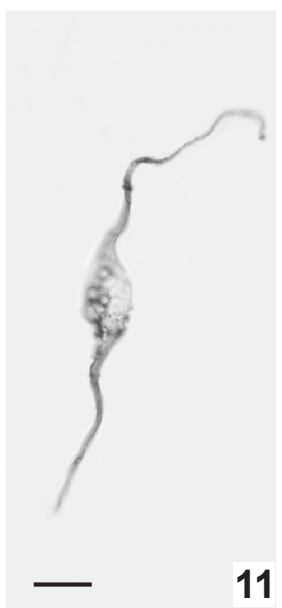

Fig. 4. 1, Eupoikilofusa striatifera (Cramer) Cramer 1970a BA Pal 5984(2) J44/3 [x0.5]. 2, Eupoikilofusa sp. cf. E. tenuistristra (Pöthe de Baldis) Pöthe de Baldis 1981 BA Pal 5984(2) Q68/2 [x0.5]. 3, Gorgonisphaeridium sp. cf. G. succinum Lister 1970 BA Pal 5992(2) L52/2. 4, Leiofusa estrecha Cramer 1964a BA Pal 5994(2) F49/3 [x0.5]. 5, Leiofusa bernesgae Cramer 1964a BA Pal 5992(2) L60/0. 6, Leiofusa exilata Dorning 1981 BA Pal 5994(2) P56/4. 7, Leiofusa tumida Downie 1959 BA Pal 5992(2) D34/2. 8, Leiofusa sp. A BA Pal 6007(1) O30/0. 9, Multiplicisphaeridium arbusculum Dorning 1981 BA Pal 5992(1) A43/3. 10, Micrhystridium sp. cf. M. stellatum Deflandre 1945 BA Pal 6005(1) Q28/0. 11, Leiofusa parvitatis Loeblich 1970 BA Pal 5992(3) K41/4. 
ment structure observed.

Dimensions. $\mathrm{V} \varnothing=13(13.5) 14 \mu \mathrm{m}, \mathrm{PL}=5(6) 7$ $\mu \mathrm{m}$ (2 specimens measured).

Remarks. The assignment of these specimens to Micrhystridium stellatum Deflandre (1945) is doubtfully since we only have two individuals, in which not all the determinant characteristics of the species could be seen.

\section{Genus Multiplicisphaeridium Staplin} emend. Lister 1970

Type species: Multiplicisphaeridium ramispinosum Staplin 1961.

\section{Multiplicisphaeridium arbusculum Dorning 1981}

(Fig. 4.9)

1974 Multiplicisphaeridium ramusculosum Deflandre; Pöthe de Baldis: 318, pl. IV, fig. 5.

Dimensions. $\mathrm{V} \varnothing=20(25) 30 \mu \mathrm{m}, \quad \mathrm{PL}=$ 23(27.3) $31 \mu \mathrm{m}, \mathrm{P} \varnothing \mathrm{B}=2 \mu \mathrm{m}, \mathrm{PN}=6-11$ (3 specimens measured).

Remarks. The material described as Multiplicisphaeridium ramusculosum Deflandre by Pöthe de Baldis (1974) display wide variations in the branching pattern. According to the characteristics depict by Fig. 5 -the presence of processes both acuminated and bifurcated and the fact that such bifurcations take place at half of the processes' length- we consider proper to reassign such material to $M$. arbusculum. Multiplicisphaeridium ramusculosum Lister (1970) processes bifurcate only distally.

\section{Multiplicisphaeridium baldisii sp. nov.} (Figs. 5.1-3, 7.9)

1974 Multiplicisphaeridium ramusculosum Deflandre; Pöthe de Baldis: 318, pl. IV, fig. 3.

2000 Evittia? escobaides Cramer emend. Sarjeant \& Vavrdová; Pöthe de Baldis: 332, pl. 3, fig, D.

Occurrence. Cachipunco Formation, Angosto Los Pereyras Section, BA Pal 5980-5992; Cumbres Los Pereyras Section, BA Pal 6004, 6006.

Type location. Angosto los Pereyras, Jujuy Province, Argentina.

Stratotype. Cachipunco Formation.

Diagnosis. Vesicle spherical, hollow, with heteromorphic processes. Eylima thick, scabrate to laevigate. Up to 13 processes, short, conical to tubiform, hollow and freely communicated with vesicle interior. Processes show different branch- ing patterns: distally bifurcated of one bifurcation at $2 / 3$ rds of the processes length and a second one at their distal ends.

Holotype. BA Pal 5988 (1) O71/1 (Fig. 5A).

Name derivation. It is named in honor to Elba Diana Pöthe de Baldis, Argentinian palynologist.

Description. Vesicle spherical, hollow, with evenly distributed, slightly heteromorphic processes. Eylima thick ( $1 \mathrm{~mm})$, scabrate to laevigate, and in some specimens slightly costate at processes bases. 6-13 sub conical to tubiform, hollow, freely communicated with vesicle interior, short (ca. $1 / 2$ vesicle diameter) processes, with laevigate to slightly granulate walls. Processes show different branching patterns, some bifurcate distally, while others show a first bifurcation at $2 / 3 \mathrm{rds}$ of the processes length and a second one at their distal ends. An excystment structure is not observed.

Dimensions. VD $=24(28.8) 33 \mu \mathrm{m}, \mathrm{PL}=$ 11(14.6) $19 \mu \mathrm{m}, \mathrm{PDB}=3(4.1) 5 \mu \mathrm{m}$ (25 specimens measured).

Remarks. This species is characterized by the shape and width of its processes, the variations in the ramification patterns and the lack of conspicuous ornamentation. The characteristics exhibit by the material described as Multiplicisphaeridium ramusculosum Deflandre by Pöthe de Baldis (1974) -wide processes and a conspicuous ramification patternallow their reinterpretation as $M$. baldisii sp. nov. Multiplicisphaeridium ramusculosum has longer and slender processes than M. baldisii. Pöthe de Baldis (2000) assigned individuals similar to $M$. baldisii to the specie Evittia escobaides (Cramer 1964b), but the latter has a polygonal vesicle and presents only one order of branching, characteristics that clearly distinguish both species.

Multiplicisphaeridium picorricum (Cramer) Lister has a larger number of processes (around 15-20), which are thinner than those of $M$. baldisii (Cramer, 1964b). Multiplicisphaeridium robertinum (Cramer, 1964b; Lister, 1970) in having more narrow processes, and a thinner eylima than $M$. baldisii.

Multiplicisphaeridium baldisii is differentiated from $M$. sp. A, as described on this work, based on the length, shape and number of the processes. It differs from $M$. sp B in the pattern of ramification of the processes. It is separated of $M$. sp C due to the shape of the processes, being in the latter mucho wider at the base, and presenting high-angled bifurcations. Also, M. sp. C has distally solid pinnulas. 
Multiplicisphaeridium eoplancktonicum (Eisenack) Lister 1970

(Fig. 5.4)

1998 Oppilatala eoplactonica (Eisenack) Dorning; Pöthe de Baldis: 14, pl. IV, figs. 10-11.

Dimensions. $\mathrm{V} \varnothing=38 \mu \mathrm{m}, \mathrm{PL}=43 \mu \mathrm{m}, \mathrm{PN}=7$ (1 specimen measured).

Remarks. Dorning (1981) transferred Multiplicisphaeridium eoplactonicum (Eisenack) Lister to Oppilatala Loeblich \& Wicander emend. Sarjeant \& Vavrdová (1997). The main characteristic to differentiate both genera is the nature of their processes. In Oppilatala, processes do no communicate freely with the vesicle interior since their bases have a basal plug, while in Multiplicisphaeridium are open to the vesicle cavity. So, if the original holotype of $M$. eoplanctonicum has their processes in free communication with the vesicle interior, as it is described, the assignment of this specie to the genus Oppilatala would be erroneous. Consequently, the assignment of this specie to the genus Multiplicisphaeridium is based on the fact that the processes are open to the vesicle interior. Multiplicisphaeridium eoplancktonicum differs from $M$. arbusculum Dorning (1981) in having a distinct branching pattern, in the former is irregular, while in the latter, the processes branch dichotomously several times. Multiplicisphaeridium ramusculosum Lister (1970) has processes that branched distally.

\section{Multiplicisphaeridium ramusculosum (Deflandre) Lister 1970} (Fig. 5.6)

Dimensions. VØ $=22(26.3) 29 \mu \mathrm{m}, \quad \mathrm{PL}=$ 21(22.3) $23 \mu \mathrm{m}, \mathrm{PN}=10(12.2) 16$ (3 specimens measured).

Remarks. Multiplicisphaeridium arbusculum Dorning (1981) has fewer processes (6-12) and they branched between one third and half of the length of the processes. It differs from $M$.? cf. eoplactonicum (Eisenack) Lister (1970) in number (4-5) and length of the processes (45 $\mu \mathrm{m}$ in the holotype).

\section{Multiplicisphaeridium variabile (Lister) Dorning 1981 \\ (Fig. 5.7)}

Dimensions. $\mathrm{V} \varnothing=22(26.3) 28 \mu \mathrm{m}, \mathrm{PL}=$ $21(22.3) 23 \mu \mathrm{m}, \mathrm{P} \emptyset \mathrm{B}=3 \mu \mathrm{m}, \mathrm{PN}=10(11) 12 ; 10$ 11 processes (3 specimen measured).
Remarks. Multiplicisphaeridium osgoodense (Cramer \& Díez) Eisenack et al. (1973) also has a polygonal vesicle, but it is larger (25$50 \mu \mathrm{m}$ ) and has fewer processes (around 6). Multiplicisphaeridium pentagonale (Stockmans \& Williérie) Mullins (2002) has fewer processes and some of them are simple. The polygonal vesicle distinguishes $M$. variabile from the other species of Multiplicisphaeridium.

\section{Multiplicisphaeridium sp. cf. M. jarillense Pöthe de Baldis 1997b}

(Fig. 5.5)

Description. Vesicle spherical, hollow, laevigate, with a thin wall. 9-17 hollow, open to vesicle cavity, laevigate processes. Processes are relatively long (around 50\% of the vesicle diameter), slender and flexuous. Distally they multifurcate in an irregular fashion. No excystment method observed.

Dimensions. $\mathrm{V} \varnothing=16(17.6) 19 \mu \mathrm{m}, \mathrm{PL}=4(7) 12$ $\mu \mathrm{m}$ (10 specimens measured).

Remarks. The assignment of these specimens to Multiplicisphaeridium jarillense Pöthe de Baldis (1997b) is based on the similarity in number and character of the processes, and in a similar relationship length of the processes/vesicle diameter. Owing to the bad state of preservation of the material is impossible to make a more exact assignment. Oppilatala ramusculosa (Deflandre) Dorning (1981) is quite similar to our specimen, but the former its processes do not communicate with the vesicle interior. Multiplicisphaeridium sp. cf. $M$. jarillense Pöthe de Baldis differs of $M$. eoplanctonicum (Eisenack) Lister (1970) in having more processes and a smaller relationship length of the process/vesicle diameter (being the processes of the latter almost twice as large as the vesicle). Multiplicisphaeridium cladus (Downie) Eisenack (1969) has a similar size and number of processes, but the branching pattern is different (wide bifurcation angle, and it may present processes distally trifurcated). Multiplicisphaeridium paraguaferum (Cramer) Lister (1970) has more processes (more than 20). Multiplicisphaeridium intonsurans (Lister) Sarjeant \& Stancliffe (1994) differs in the branching pattern (processes are barbate) and in the shape of the vesicle which is slightly polygonal. Multiplicisphaeridium variopinnum Cramer (1966) display processes which are simple or monofurcate. It differs from $M$. forquiferum (Cramer \& Díez) Eisenack et al. (1973) in having a distinct differentiation between the processes and the vesicle. 
Multiplicisphaeridium ramispinosum (Staplin) Sarjeant \& Vavrdová (1997) processes bifurcate dichotomously, has a slightly larger vesicle, and longer processes.

\section{Multiplicisphaeridium sp. A}

(Fig. 5.8)

Description. Vesicle spherical, to slightly ellipsoidal in shape, laevigate, single-layered, with 4-6 hollow, long, psilated processes. Processes communicate freely with vesicle interior. Branching occurs $1 / 2$ to $2 / 3 \mathrm{rds}$ of the processes length. Branches ramified up to the third order. No excystment method observed.

Dimensions. $\mathrm{V} \varnothing=24(27.3) 34 \mu \mathrm{m}, \mathrm{PL}=$ $22(24.1) 35 \mu \mathrm{m}, \mathrm{P} \emptyset \mathrm{B}=3(4.2) 5 \mu \mathrm{m}, \mathrm{PN}=4-6(7$ specimens measured).

Remarks. It differs from Multiplicisphaeridium arbusculum Dorning (1981) in having fewer processes; M. ramusculosum Lister (1970) has a distinct branching pattern.

\section{Multiplicisphaeridium sp. B}

(Fig. 5.9)

Description. Vesicle spherical to subspherical, hollow, thin-walled and covered with 12-20, evenly distributed, rather columnar processes. Processes bifurcate distally only once, are open to vesicle cavity, and are hollow though distally they are solid. Excystment by unornamented rupture of vesicle wall.

Dimensions. VØ $=20(25.3) 35 \mu \mathrm{m}, \mathrm{PL}=5(8) 13$ $\mu \mathrm{m}, \mathrm{PN}=11(15) 20$ (3 specimens measured).

Remarks. We assigned these specimens to the genus Multiplicisphaeridium Staplin emend. Lister because its processes present a single bifurcation distally, while in Ammonidium Lister processes equifurcate, being into two or more distally and flexible spines. It is differentiate from the other species of Multiplicisphaeridium described here due to the nature of its ramification pattern.

\section{Multiplicisphaeridium sp. C} (Fig. 5.12)

Description. Vesicle spherical, laevigated, single-layered, moderate thick-walled, 8-16 tapering, heteromorphic, open to vesicle cavity processes. Processes are hollow but distal pinnulae are solid, and may present branches up to the 4 th order. Branching occurs between 2/3rds and half the way of the processes length. No excyst- ment opening has been observed.

Dimensions. VØ $=16(20.4) 25 \mu \mathrm{m}, \mathrm{PL}=$ 6(9.4) $16 \mu \mathrm{m}, \mathrm{P} \emptyset \mathrm{B}=2(2.8) 5 \mu \mathrm{m}, \mathrm{PN}=8(9.2) 16$ (5 specimens measured).

Remarks. Multiplicisphaeridium snigirevskaiae (Stockmans \& Willèrie, 1963; Fensome et al., 1990) is similar in size and pattern of branching, but it has a hexagonal vesicle. It differs from M. pardaminum Díez \& Cramer (1976) in having shorter processes and another branching style. Multiplicisphaeridium fermosum Cramer (1970) has ramifications up to the 3rd order, and present a slightly different ramification pattern. Multiplicisphaeridium ramusculosum Lister (1970), M. arbusculum Dorning (1981), and M. eoplanctonicum (Eisenack) Lister (1970) have more flexible, longer and slender processes. It is differentiate from all the other species described here due to the characteristics of its processes (base diameter and ramification pattern). A more exact assignation could not be made due to the state in which the material is found.

Genus Neoverhyachium Cramer emend. Sarjeant \& Stancliffe 1994

Type species: Neoveryhachium carminae (Cramer) Cramer 1970.

Neoveryhachium carminae Cramer 1970

(Figs. 5.10-11)

1998 Neoveryhachium? sp. Pöthe de Baldis: 12, pl. IV, fig. 7.

1998 Veryhachium valiente Cramer; Pöthe de Baldis: 17, pl. V, figs. 8, 18.

Dimensions. VL $=16(19.9) 24 \mu \mathrm{m}, \mathrm{VW}=$ 11(14.7) $18 \mu \mathrm{m}, \mathrm{PL}=10(16.6) 30 \mu \mathrm{m}, \mathrm{P} \varnothing \mathrm{B}=$ 1.5(2.0)3 $\mu \mathrm{m}$ (23 specimens measured).

Remarks. Neoveryhachium mayhillensis Dorning (1981) is larger than $N$. carminae Cramer. According to Mullins (2001) N. carminae has also a more complex pattern of folds. Due to a preservation bias, not all the individuals observed here show the pattern of folds. The specimens described by Pöthe de Baldis as N.? sp. (Pöthe de Baldis, 1998) and Veryhachium valiente Cramer (Pöthe de Baldis, 1998) are very similar to the specimens assigned here to $N$. carminae. It has similar dimension of vesicle and processes. The absence of the characteristic fold of Neoveryhachium may be due to a preservation bias. 

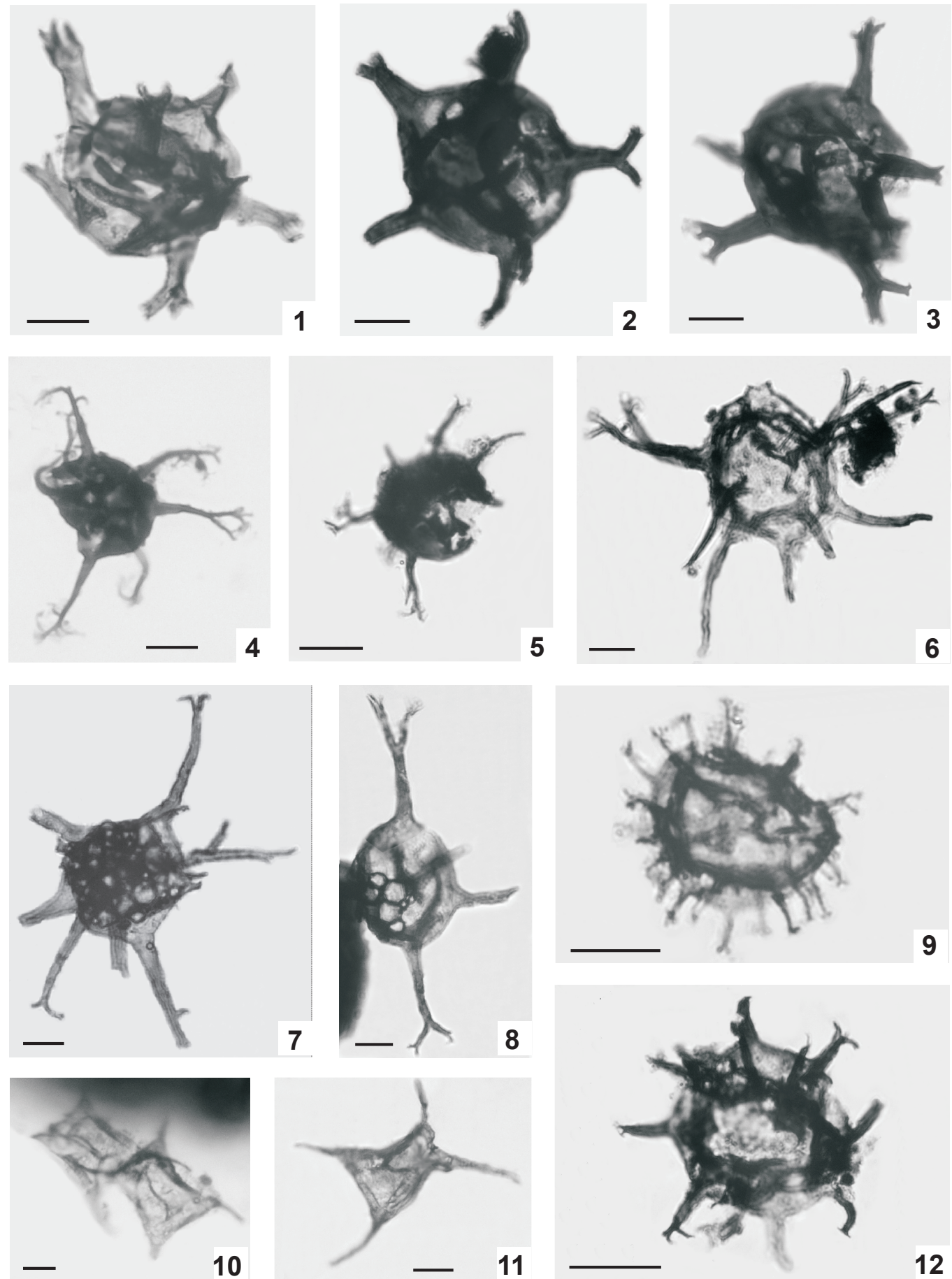

Fig. 5. 1-3, Multiplicisphaeridium baldisii sp. nov., 1, holotype, BA Pal 5988(1) O71/1; 2, BA Pal 5988(2) P43/0; 3, BA Pal 5992(2) C52/1. 4, Multiplicisphaeridium eoplanctonicum (Eisenack) Lister 1970 BA Pal 5992(4) B52/1 [x0.5]. 5, Multiplicisphaeridium sp. cf. M. jarillense Pöthe de Baldis 1997b BA Pal 5988(2) F45/0. 6, Multiplicisphaeridium ramusculosum (Deflandre) Lister 1970 BA Pal 5992(2) E53/2. 7, Multiplicisphaeridium variabile (Lister) Dorning 1981 BA Pal 5992(3) Q48/3. 8, Multiplicisphaeridium sp. A BA Pal 5992(3) E59/4. 9, Multiplicisphaeridium sp. B BA Pal 6005(1) R35/2. 10-11, Neoveryhachium carminae Cramer 1970a, 10, BA Pal 5991 Y49/1; 11, BA Pal 5988(1) S69/3. 12, Multiplicisphaeridium sp. C BA Pal 5991 G39/0. 
Genus Onondagaella Cramer emend. Playford 1977

Type species: Veryhachium asymmetricum Deunff 1954 (a nomen nudum until validated by Deunff, 1961).

\section{Onondagaella asymmetrica (Deunff) \\ Cramer 1966 \\ (Figs. 6.1, 7.4)}

Dimensions. VL $=40(59.7) 82 \mu \mathrm{m}, \mathrm{PL}=$ 10(21.6)30 $\mu \mathrm{m}$ (50 specimens measured).

Remarks. The vesicle length was measured from the broader process to the opposite size. Processes length is measured in the two identical processes.

Genus Ozotobrachion Loeblich \& Drugg 1968

Type species: Ozotobrachion dactylos Loeblich \& Drugg 1968.

\section{Ozotobrachion sp. A}

(Fig. 6.6)

Description. Vesicle triangular in outline, cushion-like, with convex sides and three processes, one arising from each corner of the vesicle. Processes tubiform, flexible, hollow, not communicated with vesicle interior, with blunt or stub distal ends. No excystment structure observed.

Dimensions. VØ $=17(21.5) 26 \mu \mathrm{m}, \mathrm{PL}=$ $12(18) 25 \mu \mathrm{m}, \mathrm{P} \emptyset=2(3) 4 \mu \mathrm{m}$ (5 specimens measured).

Remarks. Triangulina Cramer (1964b) and Ozotobrachion Loeblich \& Drugg (1968) are the two genera that posses a triangular vesicle and a double-layered wall. Ozotobrachion has processes with bifurcated distal ends, while in Triangulina processes have rounded distal ends. In the individuals recorded in Angosto Los Pereyras Section, distal ends are broken; therefore a more accurate assignment could not be made. Despite of that, and owing to the fact that Ozotobrachion has usually longer processes than Triangulina, we decided to assign these specimens to the former genus, instead of the latter.

\section{Genus Salopidium Dorning 1981}

Type species: Baltisphaeridium brevispinosum var. granuliferum Downie 1959.

\section{Salopidium sp. cf. S. granuliferum}

(Downie) Dorning 1981

(Fig. 6.7)

Description. Vesicle spherical, hollow, with a thick, foveolate wall. Processes are numerous (ca., 25), relatively short ( $1 / 3$ of the vesicle diameter), slendery columnar, tapering into simple, unbranched tips. Excystment not observed.

Dimensions. $\mathrm{V} \varnothing=25-27 \mu \mathrm{m}, \mathrm{PL}=7-8 \mu \mathrm{m}$, $\mathrm{P} \varnothing \mathrm{B}=2-3 \mu \mathrm{m}$ (2 specimens measured).

Remarks. Since the small number of specimens present, we uncertainly assigned this species based on the width of its processes, since they are much shorter and broader than in the holotype as described by Mullins (2001).

Genus Tylotopalla Loeblich emend. Sarjeant \& Vavdrová 1997

Type species: Tylotopalla digitifera Loeblich 1970.

Tylotopalla maraca Díez \& Cramer 1976 (Fig. 6.8)

Dimensions. V $\varnothing=25 \mu \mathrm{m}, \mathrm{PL}=10 \mu \mathrm{m}(1$ specimen measured).

Remarks. The transfer of Tylotopalla maraca Díez \& Cramer (1976) to the genus Dorsennidum Wicander (1974) proposed by Sarjeant \& Vavdrová (1997) is not accepted herein since Dorsennidum includes forms with polygonal vesicles determined by the acuminated and hollow processes, which range in number between 4-10 (Sarjeant \& Stancliffe, 1994). While this species has a spherical vesicle, with 10-30 processes. Salopidium granuliferum (Downie, 1959) has a foveolate wall and more and shorter processes. Ammonidium waldronense (Tappan \& Loeblich, 1971) has small rosette like spines at the processes tips.

\section{Tylotopalla robustispinosa (Downie) Eisenack et al. 1973 \\ (Fig. 6.3)}

Dimensions. V $\varnothing=13 \mu \mathrm{m}, \mathrm{PL}=5 \mu \mathrm{m}$ (1 specimen measured).

Genus Veryhachium Deunff emend. Sarjeant \& Stancliffe 1994

Type species: Veryhachium trisulcum (Deunff) Deunff 1954, subsequent designation by Downie (1959) (see Loeblich \& Tappan, 1976). 

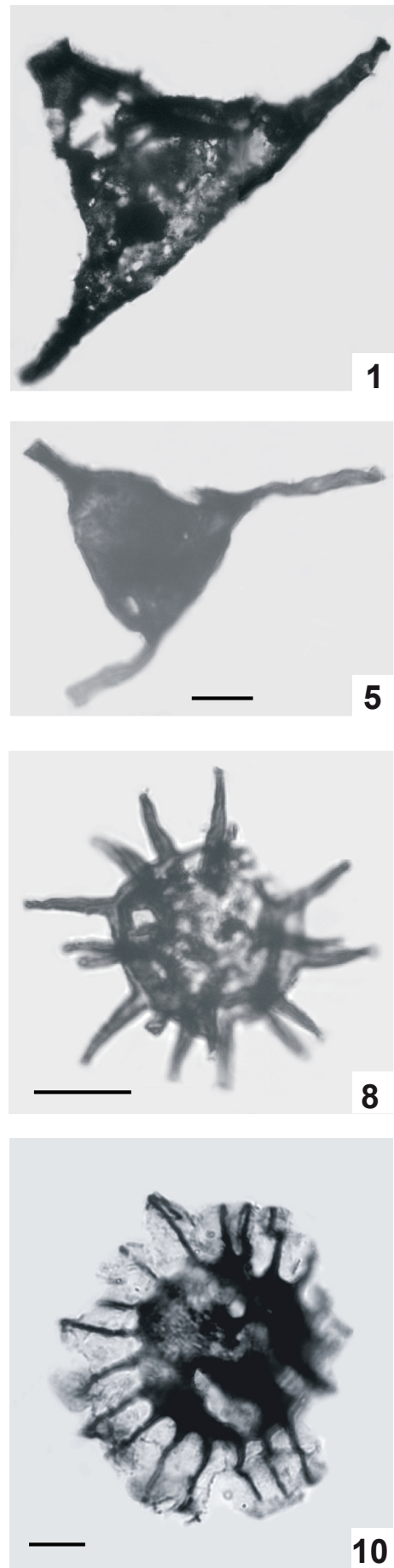
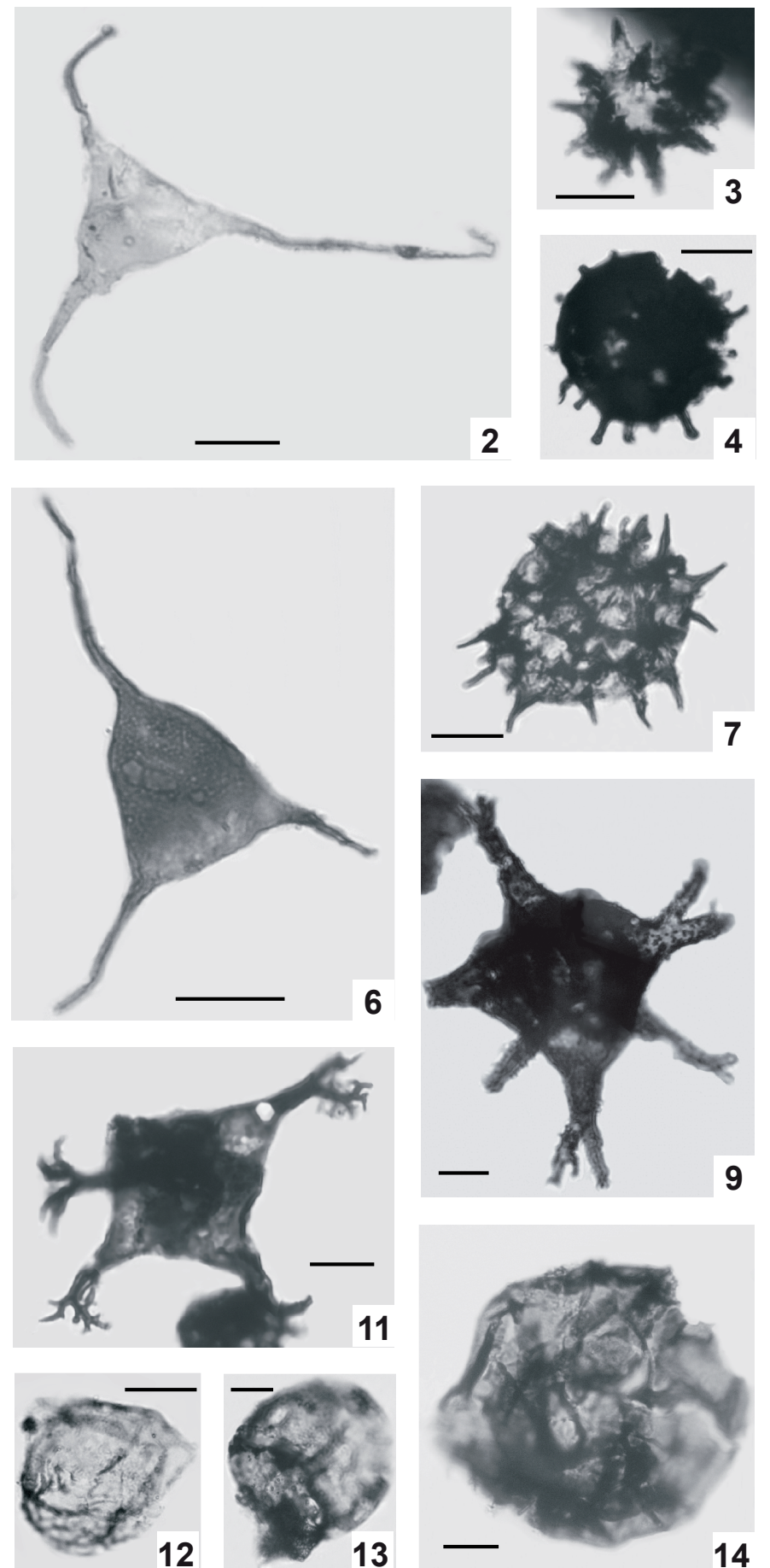

Fig. 6. 1, Onondagaella asymmetrica (Deunff) Cramer 1966 BA Pal 5988(2) F56/0. 2, Veryhachium trisphaeridium Downie 1963 BA Pal 5988(2) L50/1. 3, Tylotopalla sp. cf. T. robustispinosa (Downie) Eisenack et al. 1973 BA Pal 5992(3) J52/4. 4, Cf. Visbysphaera sp. A BA Pal 5988(2) R56/2. 5, Veryhachium trispinosum (Eisenack) Stockman \& Willière 1963 BA Pal 5988(1) J60/0. 6, Ozotobrachion sp. A BA Pal 5988(1) L68/0. 7, Salopidium sp. cf. S. granuliferum (Downie) Dorning 1981 BA Pal 6005(2) U28/0. 8, Tylotopalla maraca Díez \& Cramer 1976 BA Pal 5981 F29/0. 9, Acritarca type A BA Pal 5981 W43/1. 10, Duvernaysphaera aranaides (Cramer) Cramer \& Díez 1972 BA Pal 5988(1) U57/1. 11, Vogtlandia sp. A BA Pal 39(1) L52/1. 12, Leiosphaeridia wenlockia Downie 1959 BA Pal 5988(2) E52/3. 13, Ambitisporites avitus Hoffmeister 1959 BA Pal 5988(2) H42/1. 14, Leiosphaeridia sp. A BA Pal 5992(3) G34/2. 
Veryhachium trisphaeridium Downie 1963 (Fig. 6.2)

Dimensions. $\mathrm{V} \varnothing=17(18.3) 21 \mu \mathrm{m}, \mathrm{PL}=$ 15(23.1) $35 \mu \mathrm{m}, \mathrm{P} \varnothing \mathrm{B}=1(1.8) 2 \mu \mathrm{m}$ (16 specimens measured).

Remarks. Veryhachium trisphaeridium Downie is very similar to Dorsennidium europearum (Downie) Sarjeant \& Stancliffe (1994), although the latter has a fourth process arising perpendicular to the plane of the vesicle.

\section{Veryhachium trispinosum (Eisenack)} Stockman \& Willière 1962

(Figs. 6.4, 7.3)

Dimensions. $\mathrm{V} \varnothing=14(19.8) 25 \mu \mathrm{m}, \mathrm{PL}=$ 11(26.4) $42 \mu \mathrm{m}$ (38 specimens measured).

Remarks. Veryhachium trispinosum (Eisenack) Stockman \& Willière (1962) is differentiated from V. trisphaeridium Downie (1963) due to the thickness of its wall and the nature of its processes.

Genus Visbysphaera Lister emend. Kiryanov 1978

Type species: Visbysphaera dilatispinosa (Downie) Lister 1970.

\section{Cf. Visbysphaera sp. A \\ (Figs. 6.4, 7.10)}

Description. Vesicle spherical, with rather numerous (ca., 14), short, clavate to capitate processes. Excystment structure not observed.

Dimensions. V $\varnothing=20-31 \mu \mathrm{m}, \mathrm{PN}=6-14, \mathrm{PL}=$ 6-7 $\mu \mathrm{m}$ (2 specimens measured).

Remarks. The genus Visbysphaera Lister emend. Kiryanov is characterized by its columnar to club shaped processes and the ornamentation of the vesicle (Lister, 1970). Since in our specimens, this last characteristic is impossible to see due to the state of preservation of the material, we assigned them doubtfully to this genus.

Genus Votglandia Burmann 1970

Type species: Votglandia ramificata Burmann 1970.

\section{Vogtlandia sp. A}

(Fig. 6.11)

Description. Vesicle thin, single-walled, scabrate, quadrangular shaped, with straight to slightly convex or concave sides. 5 conical, hollow, open to vesicle interior, multifurcate (at half of the processes length) up to the fourth order processes. Such processes have very broad bases, and modify vesicle shape. No excystment method observed.

Dimensions. $\mathrm{V} \varnothing=22-28 \mu \mathrm{m}, \mathrm{PL}=15-19 \mu \mathrm{m}$, $\mathrm{P} \varnothing \mathrm{B}=6-8 \mu \mathrm{m}$ (2 specimens measured).

Remarks. These specimens are included in the genus Vogtlandia Burmann since the shape of the vesicle, number of processes and ramification pattern (Burmann, 1970). A more accurate designation is impossible to be made due to the state of preservation in which the scarce material is found.

\section{ACRITARCA INCERTAE SEDIS}

\section{Acritarca type A}

(Fig. 6.9)

Description. Vesicle polygonal in outline, formed by the coalescence of 7 to 9 conical processes. The broad-based processes are bifurcated up to three times. The first bifurcation develops at half of the process's length. Vesicle and processes evenly covered with grana and/or spines. No excystment method observed.

Dimensions. VØ $=24-31 \mu \mathrm{m}, \mathrm{PL}=22-24 \mu \mathrm{m}, \mathrm{P} \emptyset \mathrm{B}$ $=9-10 \mu \mathrm{m}, \mathrm{PN}=7-9$ ( 2 specimens measured $)$.

Remarks. This species is differentiated from Barbestiastra Downie emend. Sarjeant \& Stancliffe (1994) due to the fact that Barbestiastra has acuminate processes while this species present distal ramifications.

\section{Class PRASINOPHYCEAE Christensen 1962}

\section{Genus Duvernaysphaera Staplin emend.} Deunff 1964

Type species: Duvernaysphara tenuicingulata Staplin 1961.

\section{Duvernaysphaera aranaides (Cramer) Cramer \& Díez 1972}

(Fig. 6.10)

1971 Helios aranaides Cramer; Pöthe de Baldis: 289, pl. II, fig. 8.

1974 Duvernaysphaera jelinii Pöthe de Baldis; Pöthe de Baldis: 326, pl. I, fig. 3 .

1975a Duvernaysphaera jelinii Pöthe de Baldis: 495, pl. IV, fig. 1-2, 4-5.

1975b Helios aranaides Cramer; Pöthe de Baldis: 510, pl. III, fig. 6 . 

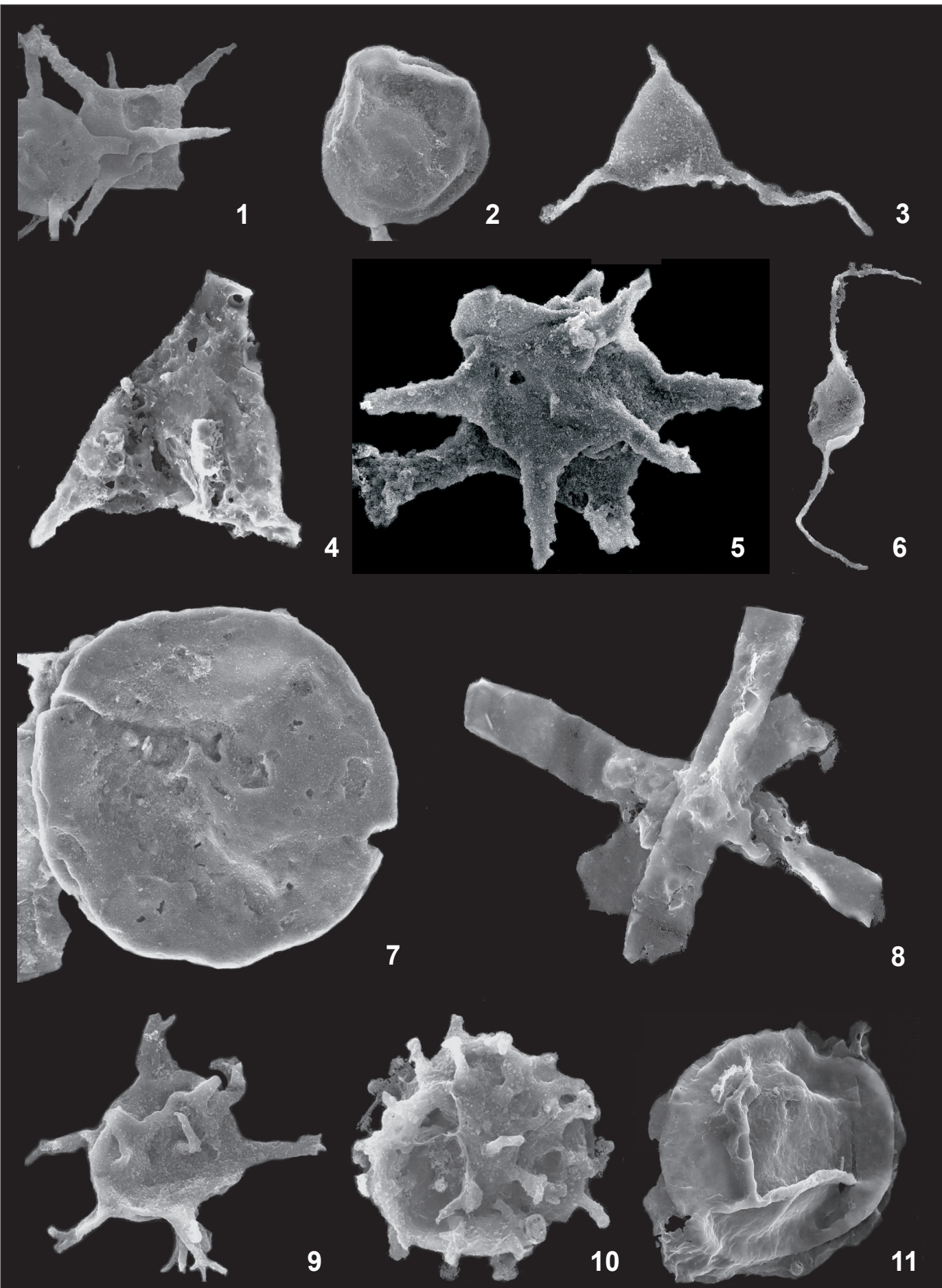

Fig. 7. 1, Diexallophasis sp. A BA Pal 5988. 2, Leiosphaeridia wenlockia Downie 1959 BA Pal 5988. 3, Veryhachium trispinosum (Eisenack) Stockman \& Willière 1962 BA Pal 5988. 4, Onondagaella asymmetrica (Deunff) Cramer 1966 BA Pal 5988. 5, Barbestiastra barbata Downie emend. Sarjeant \& Stancliffe 1994 BA Pal 5988. 6, Leiofusa bernesgae Cramer 1964a BA Pal 5988. 7, Leiosphaeridia sp. A BA Pal 5988. 8, Proteolobus cylindrus Al-Ruwaili 2000 BA Pal 5988. 9, Multiplicisphaeridium baldisii sp. nov. BA Pal 5988. 10, Cf. Visbysphaera sp. A BA Pal 5988. 11, Spore type A BA Pal 5988. 
1981 Duvernaysphaera gothica Martín; Pöthe de Baldis: 239, pl. III, figs. 1-2.

1981 Helios aranaides Cramer; Pöthe de Baldis: 243, pl. IV, figs. 10-12.

1987 Duvernaysphaera gothica Martin; Pöthe de Baldis: 92, pl. I, fig. 21.

1991 Helios aranaides Cramer; Rubinstein: 97, pl. I, figs. 2-3, 6-7.

1991 Duvernaysphaera gothica Martin; Rubinstein: 97, pl. I, figs. 1, 4-5.

1992a Helios aranaides Cramer; Rubinstein: 238, pl. II, fig. 3.

1993 Duvernaysphaera gothica Martin; Rubinstein: 70.

1993 Helios aranaides Cramer; Rubinstein: 70.

Dimensions. $\mathrm{T}=36(36.7) 49 \mu \mathrm{m}, \varnothing \mathrm{C}=17(20) 28$ $\mu \mathrm{m}, \mathrm{PL}=5(8.5) 11 \mu \mathrm{m}, \mathrm{PN}=10(14) 19, \mathrm{P} \varnothing \mathrm{B}=$ 1(1.6)2 (8 specimens measured).

Remarks. We do accept that Helios Cramer (1964b) is a junior synonym of Duvernaysphaera Staplin (1961), as discussed by Cramer \& Díez (1972), Playford (1977), Mullins (2001), among others. Duvernaysphaera jelinii Pöthe de Baldis (1974) is considered to be a junior synonym of $D$. gothica Martin (1968) by Pöthe de Baldis (1981). On the other hand, D. gothica is considered a junior synonym of $D$. aranides (Cramer) by Cramer \& Díez (1972). This latter criterion is accepted in this work.

Genus Leiosphaeridia Eisenack emend. Downie \& Sarjeant 1963

Type species: Leiosphaeridia baltica Eisenack 1958a.

\section{Leiosphaeridia wenlockia Downie 1959}

(Figs. 6.12, 7.2)

Dimensions. $\mathrm{V} \varnothing=25(27.8) 32 \mu \mathrm{m}$ (13 specimens measured).

\section{Leiosphaeridia sp. A}

(Figs. 6.14, 7.7)

Description. Vesicle spherical, thin walled $(0.5$ $\mu \mathrm{m})$, scabrated to slightly punctuated. Foldings are not distinct. Vesicle diameter varies from.

Dimensions. $\mathrm{V} \varnothing=38(44.9) 55 \mu \mathrm{m}(9$ specimens measured).

Remarks. Leiosphaeridia tenuissima Eisenack (1958b) differs only in size from the specimens described here, being the former much bigger; $L$. wenlockia Downie (1959) differs from $L$. sp. A in its size and the characteristics of its wall, being thicker and with foldings in the latter.
Anteturma SPORITES Potonié 1893

Turma TRILETES Reinsch 1881

Subturma ZONOTRILETES Waltz 1935 in

Luber \& Waltz 1938

Infraturma CRASSITI Bharadwaj \&

Venkatachala 1961

Genus Ambitisporites Hoffmeister 1959

Type species: Ambitisporites avitus Hoffmeister 1959.

Ambitisporites avitus Hoffmeister 1959

(Fig. 6.13)

Dimensions. $\varnothing=36(39.7) 45 \mu \mathrm{m}, \mathrm{Cw}=3(3.3) 4$ $\mu \mathrm{m}$ (9 specimens measured).

\section{Spore Type A}

(Fig. 7.11)

Description. Miospore trilete, radial, zonate with subcircular amb. Laesura distinct, simple, with straight sides and extending to the zone borders. Exine laevigated.

Dimensions. $\varnothing=65 \mu \mathrm{m}, \mathrm{Zw}=15 \mu \mathrm{m}$ (1 specimen measured).

\section{ALGAE INCERTAE SEDIS}

Genus Proteolobus Wood 1997

Type species: Proteolobus walli Wood 1997.

Proteolobus cylindrus Al-Ruwaili 2000

(Fig. 7.8)

Dimensions. $\mathrm{PL}=35-40 \mu \mathrm{m}, \mathrm{T}=75-80 \mu \mathrm{m}, \mathrm{P} \emptyset$

$=10 \mu \mathrm{m}$ ( 1 specimen measured $)$.

\section{MICROPLANKTON CHARACTERISTICS}

Angosto de Los Pereyras Section (Fig. 8)

The analized associations present a great diversity of species between the 10 and 140 meters, being identified more than 22 species in each level. On the other hand, in the base and the superior section of the stratigraphic column the specific diversity is much lower (between 8-17 species per level)

At a generic level, associations are clearly dominated by the Leiospaeridia genera, with minor participation of Onondogaella, Multiplicisphaeridium, Diexallophasis, Verhyachium, Neovarhyachium, and Leiofusa. 


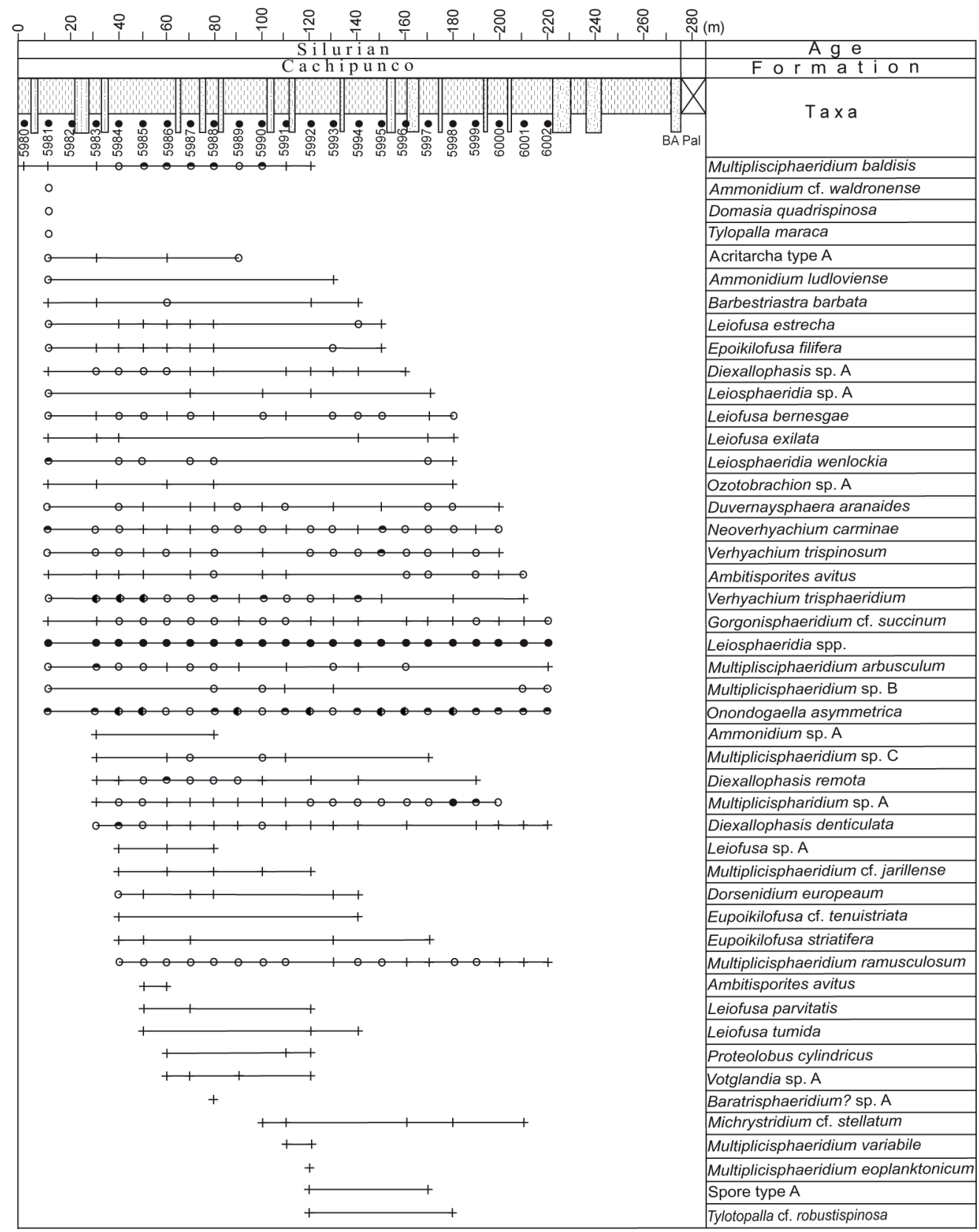

Figs. 8. Percentage distributions of the taxas identified at Angosto los Pereyras (Fig. 3) and Cumbre Los Pereyras (Fig. 4) according to the following + Less than $1 \% \bigcirc$ Between 1-5\% Between 5-10\% Between 10-20\% More than $20 \%$

In according to this, at specific level, a conspicuous predominance of Onondogaella asymmetrica, Gorgonisphaeridium succinum, Multiplicispheridium arbusculum, M. ramusculosum, Diexallophasis denticulata, Verhyachium trisphaeridium, Ambitisporites avitus, Neoveryhachium carminae, Duvernaysphaera aranaides, and Leiofusa bernesgae, among others could be observed.

A Wenlockian-Ludlovian age is inferred for this association based on the stratigraphic range of the most important species identified for it (Fig. 5).

The age for this section, as stated by Grahn \& Gutiérrez (2001) based on the chitinzoarian content, is slightly younger (Wenlokiano-Pridoliano) 


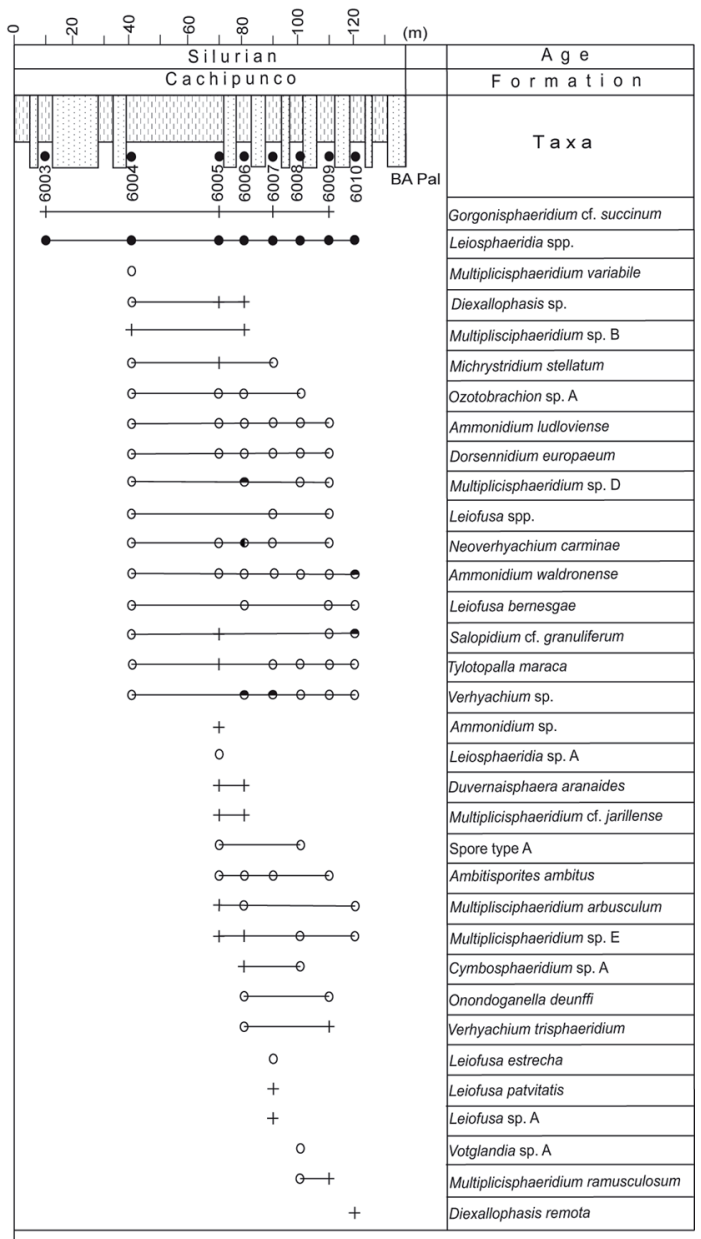

Fig. 9. Same reference as in Fig. 8.

than the age obteneid from the acritarchs (Ludlovoian-Wenlockian).

\section{Cumbre de Los Pereyras Section (Fig. 9)}

The inferior sector of this section (30 meters) comprises only one palynological association (BA Pal 6003). In that section only Leiosphaeridia and some specimens of Gorgonispaeridium where identified. Between the 40 and 120 meters, the studied associations ( 7 in total) display a moderate to low diversity (between 3-20 species per level).

In concordance withAngostoLos Pereyras, in the asssociations recovered for Cumbre Los Pereyras, preveil the genus Leiosphaeridia. Notwithstanding, this genus coexist mainly with specimens of the genera Verhyachium, Ammonidium, Dorsenidium, Multiplicisphaeridium, Tylotopalla, and Leiofusa.

The more prominent species for this section are: Gorgonisphaeridium succinum, Tylotopalla

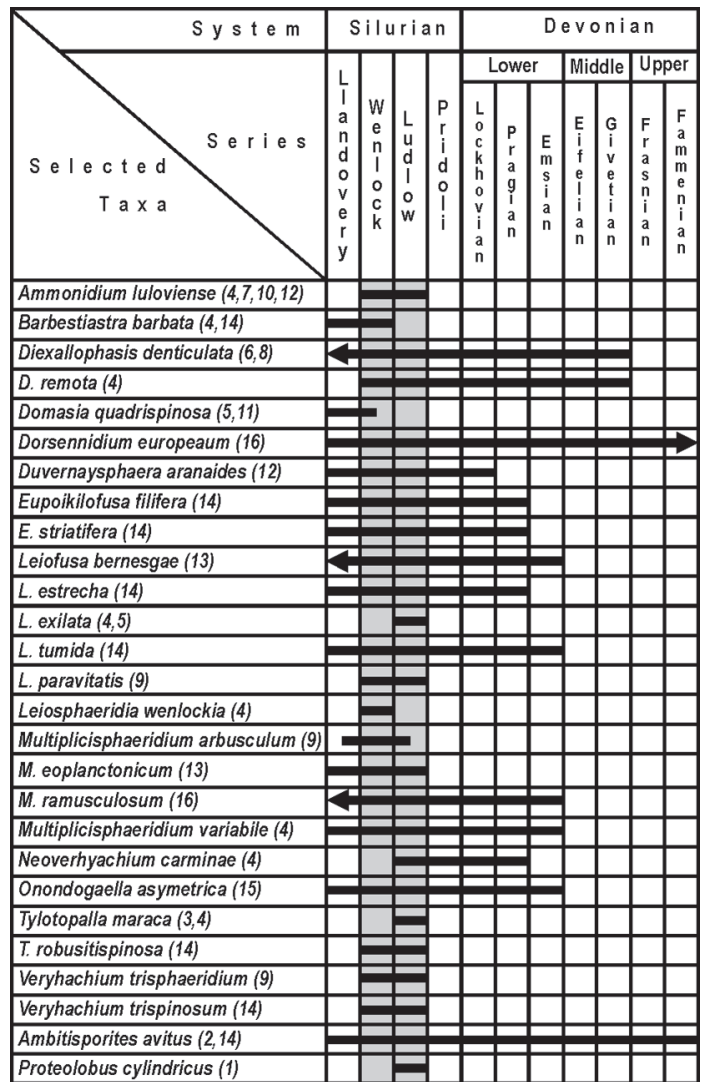

Fig. 10. Stratigraphical ranges of the more conspicuous species identified in Angosto Los Pereyras and Cumbre Los Pereyras associations. References. 1, Al-Ruwallii, 2000; 2, Cramer, 1968; 3, Díez \& Cramer, 1976; 4, Fensome et al., 1990; 5, Hill, 1974; 6, Hill \& Molyneux, 1988; 7, Lakova \& Göncüoğlu, 2005; 8, Molyneux et al., 1996; 9, Mullins, 2001; 10, Mullins, 2002; 11, Playford, 2003; 12, Rubinstein, 1992b; 13, Rubinstein, 1993; 14, Rubinstein, 1995; 15, Rubinstein \& Toro, 2006; 16, Wicander \& Playford, 1985.

maraca, Ammonidium ludloviense, A. waldronense, Dorsennidium europaeum, Neoveryhachium carminae, Leifusa bernesgae, Salopidium sp. cf. S. granuliferum y Multiplicispheridium arbusculum, among others.

Comparing these findings with those obtained for Angosto Los Pereyras, and the stratigraphic ranges of the species identified (Fig. 10), we are able to constrain the age of this section to a Welnckian-Ludlovian period.

Taking into account the previous distribution in other Argentinian formations of the identified taxones from Cachipunco Formation (Fig. 11) it is possible to notice a remarkable afinity with the palynoflore from Los Espejos Formation. 


\begin{tabular}{|c|c|c|c|c|c|c|c|c|}
\hline \multirow[b]{2}{*}{ TAXA } & \multicolumn{8}{|c|}{ FORMATION } \\
\hline & 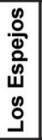 & 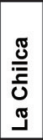 & 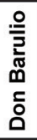 & 임 & 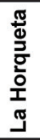 & 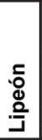 & 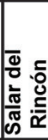 & 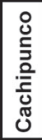 \\
\hline Leiofusa bernesgae & $\bar{X}$ & $\bar{x}$ & $\overline{\mathbf{X}}$ & $\bar{x}$ & & & & $\bar{X}$ \\
\hline Duvernaysphaera aranaides & $\mathbf{X}$ & $\mathbf{X}$ & & $\mathbf{X}$ & & & & $\mathbf{X}$ \\
\hline Eupoikilofusa striatifera & $\mathbf{x}$ & $\mathbf{X}$ & & $\mathbf{x}$ & & $\mathbf{x}$ & & $\mathbf{x}$ \\
\hline Ammonidum ludloviense & $\bar{X}$ & $\bar{X}$ & $\mathbf{X}$ & & $\mathbf{X}$ & & & $\bar{x}$ \\
\hline Diexallophasis remota & $\mathbf{X}$ & $\mathbf{X}$ & & & & & $\mathbf{X}$ & $\mathbf{x}$ \\
\hline Dorsennidium europeaum & $\mathbf{X}$ & $\mathbf{X}$ & & & & & & $\mathbf{x}$ \\
\hline Leiofusa estrecha & $\mathbf{x}$ & $\mathbf{X}$ & & & $\mathbf{X}$ & & & $\mathbf{x}$ \\
\hline Leiofusa tumida & $\mathbf{x}$ & $\mathbf{x}$ & $\mathbf{X}$ & & & & $\mathbf{x}$ & $\mathbf{X}$ \\
\hline Micrhystridium stellatum & $\mathbf{x}$ & $\mathbf{X}$ & & & & & & cf. \\
\hline Multiplicisphaeridium ramusculosum & $\mathbf{X}$ & $\bar{X}$ & & & & & & $\bar{X}$ \\
\hline Salopidium granuliferum & $\bar{X}$ & $\bar{X}$ & & & & & & cf. \\
\hline Tylotopalla robustispinosa & $\mathbf{x}$ & $\mathbf{X}$ & & & & & & cf. \\
\hline Veryhachium trisphaeridium & $\mathbf{X}$ & $\mathbf{X}$ & $\mathbf{X}$ & & & & & $\mathbf{x}$ \\
\hline Veryhachium trispinosum & $\mathbf{X}$ & $\mathbf{X}$ & & & & & & $\mathbf{x}$ \\
\hline Barbestriastra barbata & $\mathbf{X}$ & & & $\mathbf{x}$ & & & & $\mathbf{x}$ \\
\hline Diexallophasis denticulata & $\mathbf{X}$ & & $\mathbf{X}$ & $\mathbf{X}$ & & & & $\mathbf{X}$ \\
\hline Eupoikilofusa filifera & $\mathbf{X}$ & & $\mathbf{X}$ & $\mathbf{X}$ & $\mathbf{X}$ & & & $\mathbf{x}$ \\
\hline Multiplicisphaeridium variabile & $\mathbf{x}$ & & & $\mathbf{X}$ & & & & $\bar{x}$ \\
\hline Ambitisporites avitus & $\mathbf{x}$ & & & & & & & $\mathbf{X}$ \\
\hline Eupoikilofusa tenuistriata & $\mathbf{x}$ & & & & & & & cf. \\
\hline Leiosphaeridia wenlockia & $\mathbf{x}$ & & & & & & & $\mathbf{x}$ \\
\hline Multiplicisphaeridium eoplanctonicum & $\mathbf{X}$ & & & & & & & $\mathbf{x}$ \\
\hline Neoveryhachium carminae & $\mathbf{X}$ & & & & & & & $\mathbf{x}$ \\
\hline Onondogaella asymmetrica & $\mathbf{X}$ & & & & & $\mathbf{x}$ & & $\mathbf{x}$ \\
\hline Diexallophasis sp. A & $\mathbf{X}$ & & & & & & & $\mathbf{x}$ \\
\hline Ammonidium waldronense & & $\mathbf{X}$ & & & & & & cf. \\
\hline Multiplicisphaeridium jarillense & & $\mathbf{X}$ & & & & & & cf. \\
\hline Multiplicisphaeridium arbusculum & & & & & & & $\mathbf{X}$ & $\mathbf{x}$ \\
\hline Leiofusa sp. A & $\mathbf{X}$ & & $\mathbf{x}$ & & & & & $\mathbf{x}$ \\
\hline Multiplicisphaeridium baldisii & $\mathbf{X}$ & & & $\mathbf{x}$ & & & & $\mathbf{x}$ \\
\hline Domasia quadrispinosa & & & & & & & & $\mathbf{x}$ \\
\hline Tylotopalla maraca & & & & & & & & $\mathbf{X}$ \\
\hline Leiofusa exilata & & & & & & & & $\mathbf{X}$ \\
\hline Leiofusa parvitatis & & & & & & & & $\mathbf{x}$ \\
\hline Proteolobus cylindricus & & & & & & & & $\mathbf{x}$ \\
\hline
\end{tabular}

Fig. 11. Comparation of the taxas identified for Cachipunco Fm. with those found in other Argentinean formations. References: Los Espejos Fm. (Pöthe de Baldis, 1975a, 1975b, 1981, 1998; Rubinstein, 1990, 1991, 1992a, 1992b, 1993, 2000; Rubinstein \& Brussa 1999), La Chilca Fm. (Pöthe de Baldis, 1987, 1997b, 1998; Rubinstein \& Brussa, 1999), Don Braulio Fm. (Pöthe de Baldis; 1997a), Copo Fm. (Pöthe de Baldis, 1971, 1974), La Horqueta Fm. (Rubinstein, 1997), Lipeón Fm. (Rubinstein, 2005; Rubinstein \& Toro, 2006), Salar del Rincón Fm. (Rubinstein \& Vaccari, 2004).

Though the palynological association from that litostratigraphic unit is one of the better known of Argentina (see Rubinstein, 1993, 1995), is important to mention the fact that 27 species over a total of 36 , have been identified for both formations.

There are described for the first time for the Argentinian Silurian: Domasia quadrispinosa, Gorgonisphaeridium succinum, Leiofusa exi- lata, L. parvitatis, Proteolobus cylindricus, and Tylotopalala maraca.

\section{CONCLUSIONS}

The palynological content of Cachipunco Formation is described here for the first time. The following species: Domasia quadrispinosa, Leiofusa exilata, L. parvitatis, Proteolobus cylindricus y Tylotopalala maraca, are described for the first time for the Silurian of Argentina. A new species, Multipliscispharidium baldisii, is here proposed.

Finally, based on the palynological content of the Cachipunco Formation, a Wenlock-Ludlow age is assigned to this litostratigraphic unit. Such age, slightly differs from the one obteined by Grahn \& Gutiérrez (Wenlock-Pridoli, 2001), from the chitinozoarian content of this formation.

\section{ACKNOWLEDGEMENTS}

This research had been conducted with funds granted by the SECYT (research grant 12428) awarded to Pedro Raúl Gutiérrez. Dr. D. Malizia is thanked for accessing to the geological localities. We are grateful to Fabián Tricárico for the SEM and photographic assistance. We also like to thank Lic. Lucía Balarino for all the support given during this research.

\section{BIBLIOGRAPHY}

Aceñolaza F.G., G.F. Aceñolaza \& G. García. 2000. El Silúrico-Devónico del Noroeste Argentino. En: Geología Argentina, Buenos Aires, Instituto de Geología y Recursos Minerales, Anales 29(7) (1999): 205-214.

Al-Ruwaili, M.H. 2000. New Silurian acritarchs from the sub-surface of North-western Saudi Arabia. En: S. Al-Hajri \& B. Owens (Eds.), Stratigraphic Palynology of the Palaeozoic of Saudi Arabia, Gulf Petro-Link, Bahrain, p. 82-91.

Andreis, R., G. Böttcher, M. Frigerio, G. Hinterwimmer \& N. Samosiuk. 1982. Interpretación paleoambiental de la secuencia paleozoica aflorante en el Río Grande, Sierra de Zapla, Jujuy, Argentina y consideraciones sobre su edad. $V^{o}$ Congreso Latinoamericano de Geología, Buenos Aires 1982, Actas 2: 457-479.

Antelo, B. 1973. La fauna de la Formación Cancañiri (Silúrico) en los Andes Centrales Bolivianos. Revista del Museo de La Plata (Nueva serie), Sección Paleontología, 45(7): 267-277.

Antelo, B. 1978. Las Formaciones de edad Silúrica en el Noroeste Argentino (Provincias de Salta y Jujuy). Revista de la Asociación Geológica Argetina, 33(1): 
$1-16$.

Astini, R.A., B.G. Waisfeld, B.A. Toro \& J.L. Benedetto. 2004. El Paleozoico Inferior y medio de la región de Los Colorados, borde occidental de la Cordillera Oriental (provincia de Jujuy). Revista de la Asociación Geológica Argetina, 59(2): 243-260.

Baldis, B.A. 1972. Trilobites devónicos de la Sierra de Santa Bárbara, Provincia de Jujuy. Ameghiniana 9(1): 35-44.

Bellmann, R.N. 1962. Estudio geológico de la Sierra de Santa Bárbara. Publicaciones del Instituto de Geología y Minería, Universidad Nacional de Jujuy, 3(6): 7-35.

Benedetto, J.L., T.M. Sánchez \& E.D. Brussa. 1992. Las Cuencas Silúricas de América Latina. En: J.G. Gutiérrez Marco, J. Saavedra \& I. Rábano (Eds.), Paleozoico Inferior de Iberoamérica, pp. 119-148. Universidad de Extremadura.

Bharadwaj, D.C. \& B.S. Venkatachala. 1961. Spore assemblage out of a Lower Carboniferous shale from Spitzbergen. The Palaeobotanist, 10(1): 18-47.

Brito, I.M. \& A.S. Santos. 1965. Contribuçao ao conhecimiento dos micrôfósseis Silurianos e Devonianos da Bacia do Marahnao. Departamento Nacional da Produçao Mineral, Divisao de Geologia e Mineralogia, Notas Preliminares e Estudos (Rio de Janeiro, Brasil), 129: 1-21.

Bultynck, P. \& F. Martin. 1982. Conodontes et acritarches de l'Ordovicien inférieur et acritarches du Silurien inférieur de la partie septentrionale de la Cordillère Argentine. Bull. Inst. r. Sci. nat. Belg. 53, Sci. Terre 4, 21 pp.

Burmann, G. 1970. Weitere organische Mikrofossilien aus dem unteren Ordovizium. Paläontologische Abhandlungen, Abt. B, 3(3-4): 289-332.

Christensen, T. 1962. Alger. En: T.W. Böcher, M. Lange \& T. Sørensen (Eds.), Botanik (Systematisk Botanik), pp. 1-178. Munksgaard, Copenhagen.

Cramer, F.H. 1964a. Some acritarchs of the San Pedro Formation (Gedinniano) of the Cantabrian Mountains in Spain. Bulletin de la Société Belge de Géologie, 73: 33-38.

Cramer, F.H. 1964b. Microplankton from three Paleozoic formations in the province of León (NW Spain). Leidse Geologische Mededelingen, 30: 253361.

Cramer, F.H. 1966. Palynology of Silurian and Devonian rocks in Northwest Spain. Boletín del Instituto Geólogico y Minero de España, 77: 225-286.

Cramer, F.H. 1968. Palynologic microfossils of the Middle Silurian Maplewood Shales in New York. Revuè de Micropaléontologie 11: 61-70.

Cramer, F.H. 1970. Distribution of selected Silurian acritarchs. An account of the palynostratigraphy and paleogeography of selected Silurian acritarch taxa. Revista Española de Micropaleontología, Numero extraordinario: 1-203.

Cramer, F.H. \& M. del C.R. Díez. 1972. North American Silurian palynofacies and their spatial arrangement: Acritarchs. Palaeontographica, Abt. B, 158(1-4): 72-103.

Cuerda, A.J. \& Antelo, B. 1973. El límite Silúrico-
Devónico en los Andes Centrales y Orientales de Bolivia. Vo Congreso Geológico Argentino, Villa Carlos Paz (Córdoba) 1973, Actas, 3: 183-196.

Deflandre, G. 1935. Considérations biologiques sur le microorganismes d'origine planctonique conervés dans les silex de la craie. Bulletin biologique de la France et de la Belgique, 69: 213-244.

Deflandre, G. 1945. Microfossiles des calcaires siluriens de la Montagne Noir. Annales de Paléontologie, 31: 41-75.

De La Puente, G.S. \& C.V. Rubinstein. 2007. The Ordovician chitinozoans from the Western Gondwana Margin, northwestern Argentina. En: $I V^{o}$ European Meeting on the Palaeontology and Stratigraphy of Latin America, Madrid 2007, Instituto Geológico y Minero de España, Cuadernos del Museo Geominero, 8: 99-105.

Deunff, J. 1954. Veryhachium genre noveau d'hystricopherès du Primaire. Compte Rendu Sommaire des Séances de la Société Géologique de France, 13: 305-307.

Deunff, J. 1961. Quelques précisions concernant les Hystrichosphaeridées de Dévonien du Canada. Compte rendu sommaire des séances de la Société geóloique de France, 8: 216-218.

Deunff, J. 1964. Le Genre Duvernaysphaera Staplin. Grana Palynologica, 5(2): 210-215.

Díez, M. del C.R. \& F.H. Cramer. 1976. Acritarches et miospores du Ludlovien de Corniero, Province de Léon, Espagne. Revue de micropaléontologie, 19 (3): 121-133.

Dorning, K.J. 1981. Silurian acritarchs from the type Wenlock and Ludlow of Shropshire, England. Review of Palaeobotany and Palynology, 34(2): 175-203.

Dorning, K.J. 1994. Dactylofusa, Eupoikilofusa, Leiofusa and Poikilofusa: four fusiform acritarch genera. Contributions to the CIMP Symposium on Palynology, Palaeoenvironments and Stratigraphy, 6-10 September, 1994, University of Sheffield, England, pp. 15.

Downie, C. 1959. Hystrichospheres from the Silurian Wenlock Shale of England. Palaeontology, 2(1): 56-71.

Downie, C. 1963. "Hystrichospheres" (acritarchs) and spores of the Wenlock Shales (Silurian) of Wenlock, England. Palaeontology, 6(4): 625-652.

Downie, C. \& W.A.S. Sarjeant. 1963. On the interpretation and status of some hystricosphaera genera. Palaentology, 6(1): 83-96.

Eisenack, A. 1934. Neue Mikrofossilen des baltischen Silurs III und neue Mikrofossilen des böhemischen Silurs I. Palaeontologische Zeitschrift, 16(1-2): 74-118.

Eisenack, A. 1938. Hystricosphaerideen und verwandte Formen im baltischen Silur. Zeitschrift für Geschiebeforschung und Flachlandsgeologie, 14(1): 1-30.

Eisenack, A. 1958a. Tasmanites Newton 1875 und Leiosphaeridia n.g. als Gattungen der Hystrichosphaeriea. Palaeontographica, Abt. A, 110 (1-3): 1-19. 
Eisenack, A. 1958b. Mikrofossilien aus dem Ordovizium des Baltikums. 1. Markasitschicht, DictyonemaSchiefer, Glaukonitsand, Glaukonitkalk. Senckenbergiana Lethaea, 39(5-6): 389-405.

Eisenack, A. 1969. Zur Systematik einiger paläozoischer Hystrichosphären (Acritarcha) des baltischen Gebietes. Neues Jahrbuch für Geologie und Paläeontologie, Abhandlungen, 133: 245-266.

Eisenack, A., F.H. Cramer \& M. del C.R. Díez. 1973. Katalog der fossilen Dinoflagellaten, Hystrichosphären und verwandten Mickrofossilien. Band III, Acritarcha 1. Teil. E. Schweizertbart'sche Verlagsbuchahndlung, Sttutgart, 1104 pp.

Evitt, W.R. 1963. A discussion and proposals concerning fossil dinoflagellates, hystrichospheres and acritarchs. Proceedings of the National Academy of Sciences of the United States of America. Washington, 49(2-3): 158-164.

Fensome, R.A., G.L. Williams, M.S. Barss, M.J. Freeman \& J.M. Hill. 1990. Acritarchs and fossil prasinophytes: An index to genera, species and intraspecific taxa. American Association of Stratigraphic Palynologists, Contribution Series № 25.

Grahn, Y. \& P.R. Gutiérrez. 2001. Silurian and Middle Devonian Chitinozoa from the Zapla and Santa Bárbara Ranges, Tarija Basin, northwest Argentina. Ameghiniana, 38(1): 35-50.

Hagerman, T. 1933. Informe preliminar sobre el levantamiento geológico del Departamento Santa Bárbara en la Provincia de Jujuy. Boletín de Informaciones Petroleras, 10(107): 451-496.

Hill, P.J. 1974. Stratigraphic palynology of acritarchs from the type area of the Llandovery and the Welsh Borderland. Review of Palaeobotany and Palynology, 18: 11-23.

Hill, P.J. \& S.G. Molyneux. 1988. Biostratigraphy, palynofacies and provincialism of Late Ordivician-Early Silurian acritarchs from Northeast Libya. Journal of Micropaleontology, 4(1): 27-47.

Hoffmeister, W.S. 1959. Lower Silurian plant spores from Lybia. Micropaleontology, 5(3): 331-334.

Kiryanov, V.V. 1978. Akritarkhi silura Volyno-Podolii. Akademiya Nauk Ukrainskoi SSR, Institut Geologicheskikh Nauk, Kiev, Naukova Dumka: 1-116.

Lakova, I. \& M.C. Göncüoğlu. 2005. Early Ludlovian (early Late Silurian) palynomorphs from the Palaeozoic of Camdag, NW Anatolia, Turkey. Journal of the Earth Sciences Application and Research Centre of Hacettepe University, 26(1): 61-73.

Lister, T.R. 1970. The acritarchs and chitinozoa from the Wenlock and Ludlow Series of the Ludlow and Nillichope areas, Shorpshire. Monograph of the Palaeontographical Society of London, 124(1): $1-100$.

Loeblich, A.R. Jr. 1970. Morphology, Ultrastructure and distribution of Paleozoic Acritarchs. Proceedings of the North America Paleontological Convention, G: 705-788.

Loeblich, A.R. Jr. \& W.S. Drugg. 1968. New acritarchs from the Early Devonian (late Gedinnian) Haragan
Formation of Oklahoma, USA. Tulane Studies in Geology, 6(4): 129-137.

Loeblich, A.R. Jr. \& H. Tappan. 1976. Some new and revised organic-walled phytoplancton microfossil genera. Journal of Paleontology, 50(2): 301-308.

Luber, A.A. \& I.E. Waltz. 1938. Classification and stratigraphic value of some Carboniferous coal deposits in the U.S.S.R. Trudy Vsesoyznogo Geologo-Razvedochnogo Ob'edineniya NKTP. SSSR 105, 45 pp.

Martin, F. 1968. Les Acritarches de L'Ordovicien et du Silurien Belges - Determination et valeur Stratigraphique Mémoires Institut Royal des Sciencies Naturelles de Belique, 160: 1-205.

Mingramm, A. \& A. Russo. 1972. Sierras Subandinas y Chaco Salteño. En: A.F. Leanza (ed.), Geología Regional Argentina, pp 185-211. Academia Nacional de Ciencias de Córdoba.

Mingramm, A., A. Russo, A. Pozzo \& L. Cazau. 1979. Sierras Subandinas. IIo Simposio de Geología Regional Argentina, Córdoba 1979, Academia Nacional de Ciencias, 1: 95-137.

Molyneux, S.G., A. Le Hérissé, \& R. Wicander. 1996. Paleozoic Phytoplankton. En: J. Jansonius \& D.C. McGregor (Eds.), North American Silurian palynofacies and their spatial arrangement: Acritarchs. Chapter 16. Palynology: Principles and Applications, 2: 493-529.

Monaldi, C.R. \& M.A. Boso. 1987. Dalmanitina (Dalmanitina) subandina nov.sp. (Trilobita) en la Formación Zapla del norte Argentino. IV ${ }^{\circ}$ Congreso Latinoamericano de Paleontología, Santa Cruz de la Sierra (Bolivia) 1987, Actas 1: 149-158.

Moreau-Benoit, A. 1974. Recherches de Palynologie et de Planctologie. Sur le Dévonien et quelques formations siluriennes dans le Sud-Est du Massif Armoriacan. Mémoires de la Société géologique et minéralogique de Bretragne, 18: 1-248.

Moreno Espeleta, C., J.E. Arias \& A. Chávez. 1981. Geología del área termal de Santa Bárbara, Provincia de Jujuy, República Argentina. VIII ${ }^{o}$ Congreso Geológico Argentino, San Luis 1981, Actas 3: 713-732.

Mullins, G.L. 2001. Acritarchs and prasinophyte algae of the Elton Group, Ludlow Series, of the type area. Monograph of the Palaeontographical Society of London, 155: 1-154.

Mullins, G.L. 2002. Revision of acritarchs and prasinophyte algae from the lower Silurian of Belgium. Journal of Micropalaeontology, 21: 87-94.

Mullins, G.L. 2004. Microplankton biostratigraphy of the Bringewood Group, Ludlow Series, Silurian, of the type area. Journal of Systematic Palaeontology, 2(3): 163-205.

Padula, E.L., E.O., Rolleri, A.R.G. Mingramm, P. Criado Roqué, M.A. Flores \& B.A. Baldis. 1967. Devonian of Argentina. Procceding of the International Symposium on the Devonian System, Calgary, 2: 165-199.

Pezzi,E.E.\&M.E.Mozetic. 1990.Cuencas Sedimentarias de la región Chacoparanaense. En: G. Chebli \& L.A. Spalletti (Eds), Serie de Correlación Geológica № 6 (1989): Cuencas Sedimentarias Argentinas, pp. 65- 
78. Universidad Nacional de Tucumán, Instituto Superior de Correlación Geológica.

Playford, G. 1977. Lower to Middle Devonian acritarchs of the Moose River Basin, Ontario. Geological Survey, Bulletin, 279: 1-87.

Playford, G. 2003. Acritarchs and prasinophyte phycomata: a short course. American Association of Stratigraphic Palynologists, Contributions Series, 41: 1-39.

Pöthe de Baldis, E.D. 1971. Microplancton del Silúrico superior de la provincia de Santiago del Estero, República Argentina. Ameghiniana, 8 (3-4): 282290.

Pöthe de Baldis, E.D. 1974. Microplancton adicional del Silúrico superior de Santiago del Estero, República Argentina. Ameghiniana, 11(4): 313-327.

Pöthe de Baldis, E.D. 1975a. Microplancton del Wenlockiano de la Precordillera Argentina. Revista Española de Micropaleontología, 7(3): 489-505.

Pöthe de Baldis, E.D. 1975b. Microplancton de la Formación Los Espejos, Provincia de San Juan, República Argentina. Revista Española de Micropaleontología, 7(3): 507-518.

Pöthe de Baldis, E.D. 1981. Paleomicroplancton y mioesporas de Ludloviano inferior de la Formación Los Espejos en el perfil Los Azulejitos, en la provincia de San Juan, República Argentina. Revista Española de Micropaleontología, 13(2): 231-265.

Pöthe de Baldis, E.D. 1987. Microplancton del Llandoveriano Superior-Wenlockiano inferior. Asociación de Deunffia y Domasia, de la Formación La Chilca, Aguada de los Azulejitos, San Juan, Argentina. $X^{o}$ Congreso Geológico Argentino, San Miguel de Tucumán, Actas 3: 89-94.

Pöthe de Baldis, E.D. 1997a. Acritarcas del Llandoveriano temprano-medio de la formación Don Braulio, Precordillera Oriental, Provincia de San Juan, Argentina. Revista Española de Micropaleontología, 29(1): 31-68.

Pöthe de Baldis, E.D. 1997b. Acritarcas y prasinofíceas del Llandoveriano temprano-medio de la Formación La Chilca, quebrada de Talacasto, provincia de San Juan, Argentina. Ameghiniana, 34(4): 461-479.

Pöthe de Baldis, E.D. 1998 Acritarcas de la formación Los Espejos (Silúrico superior) del perfil Aguada de los Azulejitos, San Juan, Argentina. Revista Española de Micropaleontología, 30(2): 1-18.

Pöthe de Baldis, E.D. 2000. Palinomorfos de la Formación Los Espejos (Ludloviano medio-tardío) de Aguada de Los Azulejitos, Precordillera central, San Juan, Argentina. Ameghiniana, 37(3): 327-339.

Potonié, H. 1893. Die Flora des Rothliegenden von Thüringen. Preussische Geologische Landesanstalt, Abhandlugen 9: 1-298.

Priewalder, H. 1987. Acritarchen aus dem Silur des Cellon-Profils, Karnische Alpen, Österreich. Abhandlungen der Geologischen Bundesanstalt, Wien, 40: 1-121.

Reinsch, P.F. 1881. Neue untersuchungen über die mikrostruktur der Steinkohle des karbon, der Dyas und Trias. T. O. Weigel, Leipzig, 124 p.
Rubinstein, C.V. 1990. Acritarcos del Silúrico del Valle del Río Jáchal (Formación Los Espejos), provincia de San Juan, República Argentina. Subgrupos Herkomorphitae, Netromorphitae y Polygonomorphitae. Ameghiniana, 26(1989)(1-2): 83-100.

Rubinstein, C.V. 1991. Acritarcos del Silúrico del Valle del Río Jáchal (Formación Los Espejos), provincia de San Juan, República Argentina. Subgrupos Prismatomorphitae, Pteromorphitae y acritarcos de ubicación incierta. Ameghiniana, 27(1990) (1-2): 95-106.

Rubinstein, C.V. 1992a. Palinología del Silúrico Superior (Formación los Espejos) Quebrada de las Aguaditas, Precordillera de San Juan, Argentina. Ameghiniana, 29(3): 231-248.

Rubinstein, C.V. 1992b. Palinología del Silúrico Superior (Formación los Espejos) de Loma de los Piojos, Precordillera de San Juan, Argentina. Ameghiniana, 29(4): 287-303.

Rubinstein, C.V. 1993. Acritarchs from the Upper Silurian of San Juan, Argentina: Bioestratigraphy and Palaeobiography. Special papers in Palaeontology, 48: 67-78.

Rubinstein, C.V. 1995. Acritarchs from the upper Silurian of Argentina: their relationship with Gondwana. Journal of South American Earth Sciences, 8(1): 103-115.

Rubinstein, C.V. 1997. Primer registro de palinomorfos silúricos en la Formación La Horqueta, Bloque de San Rafael, Provincia de Mendoza, Argentina. Ameghiniana, 34(2): 163-167.

Rubinstein, C.V. 2003. Ordovician acritarchs from northwestern Argentina: new insight into the biostratigraphy and paleoenviromental aspects on the Central Andean Basin and Famatina. En: G.L. Albanesi, M.S. Beresi \& S.H. Peralta (Eds), Ordovician from the Andes. Proccedings of the $9^{\text {th }}$ International Symposium on the Ordovician System. INSUGEO, Serie de Correlación Geológica, Tucumán, 17: 125-130.

Rubinstein, C.V. 2005. Ordovician to Lower Silurian palynomorphs from the Sierras subandinas (Subandean Ranges), Northwestern Argentina: a preliminary report. Carnets de Géologie, Memoir 2005, 2(09): 51-56.

Rubinstein, C.V. \& E.D. Brussa. 1999. A palynomorph and graptolite biostratigraphy of the Central Precordillera Silurian Basin. En: M. Tongiorgi \& G. Playford (Eds), Studies in Palaeozoic Palynology. Selected Papers from the CIMP Symposium at Pisa, 1998. Bolletino della Società Paeontologica Italiana, 38(2-3): 257-276.

Rubinstein, C.V. \& B.A. Toro. 2006. Aeronian (Llandovery, Lower Silurian) palynomorphs and Graptolites from the Lipeón Formation Eastern Cordillera, North-West Argentina. Geobios, 39: 103-111.

Rubinstein, C.V. \& N.E. Vaccari. 2004. Criptospore assemblages from the Ordovician/Silurian boundary in the Puna Region, North-West Argentina. Palaeontology, 47(4): 1037-1061. 
Rubinstein, C.V., G.S. De La Puente, T. Servais, M. Vecoli \& R.A. Astini. 2007. Advances in the Ordovician palynology of Argentina: biostratigraphy and paleobiogeography. En: E. Díaz-Martínez \& I. Rábano (Eds.), IVo European Meeting on the Palaeontology and Stratigraphy of Latin America, Madrid, Cuadernos del Museo Geominero, $n^{-} 8$. Instituto Geológico y Minero de España, pp. 349354.

Sánchez, T.M. 1990. Bivalvos paleotaxodónicos de la Formación Lipeón (Silúrico) de la Sierra de Zapla, Provincia de Jujuy, Argentina. Ameghiniana, 26(1989) (3): 173-189.

Sarjeant, W.A.S. \& R.P.W. Stancliffe. 1994. The Micrhystridium and Veryhachium complexes (Acritarcha: Acantomorphitae and Polygonomorphitae) a taxonomic reconsideration. Micropaleontology, 40(1): 1-77.

Sarjeant, W.A.S. \& M. Vavrdová. 1997. Taxonomic reconsideration of Multiplicisphaeridium Staplin, 1961 and other acritarch genera with branching processes. Geolines (Praha), 5: 1-52.

Schlagintweit, O. 1943. La posición estratigráfica del yacimiento de hierro de Zapla y la difusión del horizonte glacial de Zapla en la Argentina y Bolivia. Revista Minera, Sociedad Argentina de Mineralogía y Geología. 13: 115-127.

Staplin, F.L. 1961. Reef-controlled distribution of Devonian microplankton in Alberta. Paleontology, 4(3): 392-424.

Staplin, F.L., J. Jansonius \& S.A.J. Pocock. 1965. Evaluation of some acritarchous hystrichosphere genera. Neues Jahrbuch für Geologie und Paläontologie, Abhandlungen, 123(2): 167-201.

Starck, D. 1995. Silurian-Jurassic stratigraphy and basin evolution of North-western Argentina. En: A.J. Tankard, R. Suárez S. \& H.J Welsink, Petroleum basins of South America, pp. 251-267. American Association of Petroleum Geologists Memoir 62.

Stockmans, F. \& Y. Willière. 1960. Hystrichosphères du Dévonien belge (Sondage de l'Asile d'alienés à Tournai). Senckenbergiana Lethaea, 41(1-6): 1-11.
Stockmans, F. \& Y. Willière. 1963. Les hystrichosphères ou mieux les acritarches du Silurien belge. Sondage de la Brasserie Lust à Courtrai (Kortrijk). Bulletin de la Société Belge de Géologie, de paleontologie et d'Hydrologie, 71(3): 450-481.

Tappan, H. \& A.R. Jr. Loeblich.1971. Surface sculpture of the wall in Lower Paleozoic acritarchs. Micropaleontology, 17(4): 385-410.

Turner, J.C.M. 1960. Estratigrafia de la Sierra de Santa Victoria y adyacencias. Boletín de la Academia Nacional de Ciencias de Córdoba, 41(2): 163-196.

Vistalli, M.C. 1990. La Cuenca Siluro Devónica del Noroeste. En: G. Chebli \& L.A. Spalletti (Eds.), Serie de Correlación Geológica No 6 (1989): Cuencas Sedimentarias Argentinas, pp. 19-41. Universidad Nacional de Tucumán, Instituto Superior de Correlación Geológica.

Wicander, E.R. 1974. Upper Devonian-Lower Mississippian acritarchs and prasinophycean algae from Ohio, USA. Palaontographica, Abt. B, 148: 9-43.

Wicander, E.R. \& G. Playford. 1985. Acritarchs and Spores from the Upper Devonian Lime Creek Formation, Iowa, U.S.A. Micropaleontology, 31(2): 97-138.

Wicander, E.R. \& G. Wood. 1981. Systematics and biostratigraphy of the organic-walled microphytoplacton from the Middle Devonian (Givetian) Silica Formation, Ohio, U.S.A. American Association of Stratigraphic Palynologists, Contribution Series Number, 8: 1-137.

Wood, G.D. 1997. The acritarch Proteolobus wallii gen. et sp. nov. from the Devonian Iquiri Formation of Bolivia: a possible coenobial alga. Micropalaeontology, 43(3): 325-331.

Wood, G.D., A.M. Gabriel \& J.C. Lawson. 1996. Palynological techniques-processing and microscopy. En: J. Jansonius \& D.C. McGregor (Eds.), Palynology: principles and applications 1: 29-50. American Associations of Stratigraphic Palynologists Foundation, Dallas. 
